\title{
TREATY RELATIONS OF THE PEOPLE'S REPUBLIC OF CHINA: A STUDY OF COMPLIANCE *
}

\author{
LUKE T. LEE $\dagger$ \\ By their fruits ye shall know them. \\ Matthere 7:20
}

\section{INTRODUCTION}

The attitudes of the People's Republic of China (PRC) towards international law have been the object of several inquiries in recent years. ${ }^{1}$ Valuable as these studies are in providing information on the background and theories of Chinese international law, no systematic analysis of China's actual conduct in relation to treaty obligations has been undertaken. ${ }^{2}$ Yet the importance of treaty practice and com-

* This paper was written under the auspices of the United Nations Association of the United States of America for the use of its China Panel. The views expressed herein, however, do not necessarily reflect those of the UNA-USA or the Panel, and responsibility for the content of the paper is entirely the author's. The author cannot express adequately his appreciation and gratitude to officials in different countries who have given their assistance and cooperation.

$\dagger$ B.A. 1944, St. John's University (Shanghai) ; M.A. 1947, Columbia University; Ph.D. 1954, Fletcher School of Law and Diplomacy; LL.B. 1963, University of Michigan. Director, New York Office, Rule of Law Research Center, Duke University. Lecturer in Law, New York University School of Law.

1 See, e.g., Dicks, Chinese Attitudes to International Law (Royal Institute of International Affairs, Working Group on China and the World, undated); Beauté, Le Répnblique Populaire de Chine et le Droit International, 68 REv. GEN. DE Drorr INT'r. PUBLIC 350 (1964); Chiu, Communist China's Attitude Toward International Law, 60 Am. J. InT's L. 245 (1966) ; Edwards, The Attitude of the People's Republic of China Toward International Law and the United Nations, in 17 PAPERS ON CEINA (Harvard University East Asian Research Center, Dec. 1963); Leng, Communist China's Position on Nuclear Arms Control, 7 VA. J. INT'1 L. 101 (1966); Steiner, Conmmunist China in the World Community, INT'i Concrliatron, No. 533, at 387 (May 1961).

2 A few statements of a denunciatory nature have appeared from time to time. The Department of State, for example, in 1963 compiled a study on The Conduct of Communist China for the use of the House Committee on Foreign Affairs, 88th Congress, 1st Session. It accused the PRC of four violations of specific agreements: two relating to the 1953 Korean Armistice Agreement, one to the 1955 "agreement" on the repatriation of Chinese and American civilians and one to the 1954 Sino-Indian agreements concerning Tibet. Since the first three affect the United States-PRC relations directly, they are examined in detail in the present study. See text accompanying notes 59-80 infra. Deterioration of Sino-Indian treaty relations over Tibet, since it is an immediate outgrowth of the absence of a boundary treaty, will not be discussed in this paper.

Many more studies, some systematic and analytical, have been undertaken on Soviet compliance with treaty obligations. See, e.g., INTERNal. SECURITY Subcomm. of the Senate Comar. on Foreign Retations, 84th Cong., 2D Sess., Report re Russian Broken Promises (Comm. Print 1962); Report of the A.B.A. Special Committee on CoMmunist Tactics, Strategies, and Objectives (1959) (this report 
pliance cannot be overemphasized. ${ }^{3}$ Assuming the existence of a correlation between a country's past record of treaty compliance and its future conduct, a study of past treaty practice could provide a basis by which to predict and anticipate Chinese policy and activities in regard to future treaties. Furthermore, China traditionally has regarded itself as the center of the universe and head of the Confucian family of nations, whose existence long antedated the much younger and essentially Western discipline of international law. It is understandable, therefore, that China might feel reluctant to be bound by Western customary law, in the making of which it did not participate. Treaties, on the other hand, as expressions of consent, remain the logical source of international law for China. ${ }^{4}$

This emphasis on treaty-centered international law is far from discouraging, for relations between states are more and more governed by treaties, ${ }^{5}$ and customary international law is increasingly becoming crystallized into conventional international law. ${ }^{6}$ Even the Charter of the United Nations is itself a treaty, sui generis though it may be. The impending codification of the law of treaties, planned for 1968-

has not been endorsed by the ABA) ; U.S. DEP'T of DEFENSE, SovIET TrEaty VIolations: Alert No. 5 (1962); U.S. Dep't of State, Background Information on THE Soviet Union in InTERNational Rexatrons (printed for use of the House Comm. on Foreign Affairs, 87th Cong., 1st Sess. (Sept. 27, 1961)). See also Memorandum from the Department of State on Soviet Treaty Violations, Aug. 22, 1963 in Hearings on the Nuclear Test Ban Treaty Before the Senate Comm. on Foreign Relations, 88th Cong., 1st Sess. 967-68 (1963) (listing agreements observed generally by the Soviet Union).

The Defense Department study, supra, appears to reflect the general theme that "Officials of the Soviet Union, from the 1917 Bolshevik revolution onward through 45 years of Communist rule, have established an undisputed reputation for breaking their most solemn pledges." ALERT No. 5 , supra at 2 . It may be wondered to what extent this finding of consistent treaty violations by the first and most powerful Communist state has been assumed to be true with respect to all other Communist states, including the PRC, and may have constituted the basic premises of U.S. policies towards the Far East and Southeast Asia.

3 Speaking at the opening of the World Peace through Law Conference in Geneva, Chief Justice Earl Warren urged the lawyers of the world to sponsor the negotiation of "hundreds and perhaps thousands" of treaties to regulate all phases of international relations. "Instead of matching each other soldier for soldier, plane for plane, bomb for bomb and missile for missile," he called upon nations to compete with each other "law for law, treaty for treaty." Treaty compliance in such a "law-full" world would render war obsolete. See N.Y. Times, July 11, 1967, at 11, col. 2.

4 For a Chinese view regarding treaties as the major source of international law, see Wei Liang, On International Treaties Concluded Since World War II, Kuo-CHI T'rAO-YÜEH CHI (International Treaty Series), 1953-1955, at 660 (Peking, 1961). For Soyiet views, see ACADEMY OF SCIENCES OF THE U.S.S.R., INTERNATIONAI LAW 12 (English transl. 1961); J. Triska \& I. Slusser, The Theory, LAw, AND Poltcy of Soviet Treaties 9-31 (1962).

5 The following statistics may be of interest: A total of 579 treaties or international agreements were registered with the United Nations Secretariat during the year ending June 15, 1967. The figure for the period of December 14, 1946-June 15, 1967, was 12,636. See Annual Report of the Secretary General on the Work of the Organization, June 16, 1966-June 15, 1967, 22 U.N. GAOR Supp. 1, at 182, U.N. Doc. A/6701 (1967).

6 See Lee, International Law Commission Re-examined, 59 AM. J. INT'L L. 545, 568 (1965). 
$19697^{7}$ will further facilitate the conclusion and implementation of treaties as well as the settlement of disputes arising therefrom.

A study of Chinese treaty relations at this time may serve another important purpose. Hitherto, arguments for and against Peking's representation at the United Nations have centered, rightly or wrongly, on her ability and willingness to fulfill obligations arising under the Charter of the United Nations. The absence of a systematic study of Chinese treaty practice has left this essentially legal question to the realm of emotional speculation. Since informed public opinion can contribute significantly to intelligent foreign policy, it is time to subject the question of Chinese treaty compliance to critical legal scrutiny.

\section{METhodology}

An obvious limitation to the present study is the inability of the author to travel to mainland China to consult its archives and interview its officials. However, since the study is aimed at determining the actual treaty compliance record of the PRC, judged by performance observable by the outside world and particularly by its co-signatories, the inaccessibility of mainland China has not posed an insuperable barrier. A substantial portion of the research was conducted in Japan, which has the finest collection of Chinese materials, both classical and contemporary, outside China. In addition, Japan's proximity to China and its relative intellectual freedom on the subject of China facilitated the present research. It may be noted that Japan leads all other countries in: (a) the number of visitors to China, (b) the number of newsmen (nine) stationed in China, (c) the amount of news published concerning China and (d) the volume of trade with China. For these reasons, many countries have sent their China experts to Tokyo as diplomats. These diplomats are less restrained in discussing China than are their colleagues in the United States, whose reluctance to talk is understandable in view of the known position of the host country.

Government officials, including diplomats, generally are reluctant to be quoted directly, especially in regard to subject matter as sensitive as China. Almost all government officials insisted as a precondition for granting interviews that the talks be held off-the-record. This sensitivity extended to unpublished official documents, which were made available to the author for background information, but could not be cited directly without prior authorization. Such authorization only could be obtained, if at all, through proper channels and after interminable delays. The author, therefore, occasionally has been

7 See G.A. Res. 2166, 21 U.N. GAOR Supp. 16, at 95, U.N. Doc. A/6316 (1966). 
compelled to follow the journalistic practice of referring to unnamed "reliable sources," rather than suppressing valuable information and avoiding discussion of vital issues. The choice between the two alternatives involves a serious dilemma: whether one should desist from examining an issue of great importance and publishing his findings because the materials involved are not generally accessible to the public or because their sources cannot be revealed. It is the author's view that one who possesses special information affecting public welfare and security has an obligation to use it to public advantage, provided adequate safeguards are adopted to minimize inaccuracy and bias.

In the course of this investigation, the author selected for interviews individuals who are or were in positions which have brought them into close contact with the PRC. 8 While substantial research was undertaken in Toyo Bunko and the main Diet Library in Japan, the search for primary source materials took the author to almost all Far Eastern countries outside mainland China, and to the United Nations Command in Seoul, the neutral nations' compound in Panmunjom and the Ministries for Foreign Affairs in Stockholm and Helsinki.

Information thus collected was scrutinized with respect to possible motivation, consistency with known facts and corroboration by independent sources. For example, in studying Chinese compliance with economic assistance agreements, the author took cognizance of the human tendency to praise the generosity of gift donors. Corroborative evidence was required to show that a specific project was indeed completed according to agreement. Since detailed information on the content of such agreements and on the condition of the completed project was unavailable, the author has refrained from reaching any conclusion concerning the PRC's compliance with aid agreements, despite the unanimous opinion of diplomats interviewed on the subject that the Chinese compliance record was excellent.

Another research problem concerned the selection of countries and treaties for inclusion in the present study. Obviously, it would not be feasible to cover all the treaties concluded by Peking since 1949. In addition, there may well be treaties whose existence or breach has escaped the author's notice. Subject to these limitations, the author was guided in his selection by the importance of the subject matter, the need for balanced representation and an intent to give priority to China's treaties with her immediate neighbors.

8 Among these were 11 Ambassadors, 3 Deputy Chiefs of Missions, 6 Counsellors, 10 First and Second Secretaries, 5 Legal Advisers, 2 Directors of Intelligence and Research, 2 Chiefs of Sections in the China Bureau of a Foreign Office, 1 General Officer, 2 Colonels, and innumerable editors and reporters of newspapers and magazines interested in China. In addition, talks were held with responsible officials of the United Nations in Japan and Korea, the Japan-China Fisheries Council, the Canadian Wheat Board and even a "friendly firm." 
Omitted from detailed study were those treaties couched in general terms, such as the seventeen treaties of peace, friendship or nonaggression concluded between 1950 and $1965 .^{\circ}$ These treaties stress the promotion of cultural and economic cooperation and the five principles of peaceful coexistence: mutual respect for territorial integrity and sovereignty, non-aggression, non-interference in internal affairs, equality and mutual benefit, and peaceful coexistence. ${ }^{10}$ These general treaties also occasionally call for respect for the principles of the Charter of the United Nations. ${ }^{11}$ Specific obligations are usually limited to settlement of disputes by peaceful negotiation and some bar each party from entering into military alliances directed against the other.

Similarly omitted from discussion by the terms of reference set for this study are disputes which did not owe their origin to applicable treaties, such as the Sino-Indian border disputes (which stemmed from the absence of a boundary treaty), the various incidents involving diplomatic immunities (which resulted from the fact that the PRC is not a signatory to the 1961 Vienna Convention on Diplomatic Relations ${ }^{12}$ ) and the conflicts over Tibet (which, as a part of China, cannot have treaty relations with it).$^{13}$

While the importance of Peking's attitudes towards treaties concluded before 1949 cannot be denied, time is not yet ripe for such a

9 These treaties are published in CHUNG-HUA JEN-MIN KUNG-HO-KUO YU-HAO T'IAC-YÜEH HuI-PIEN, (1965) (Collection of Goodwill Treaties of the People's Republic of China) [hereinafter cited as PRC Goodwrus TREATIES].

10 The five principles were first incorporated in the Sino-Indian treaty of 1954 on trade and intercourse between India and Tibet. See text in 3 CHUNG-HUA JEN-MIN KunG-HO-KUO T'IAO-YÜEH CHI 1-4 (1954) (Treaty Series of the People's Republic of China) [hereinafter cited as PRC TREATY SERIEs]. Since then, China has included these principles in many treaties, particularly goodwill treaties. See note 9 supra.

${ }^{11}$ See, e.g., 1960 Treaty of Friendship and Mutual Non-Aggression Between China and Afghanistan, PRC Goopwill. Treatres 18; 1957 Treaty of Friendship and Cooperation Between China and Czechoslovakia, id. at 93.

12 U.N. Doc. A/CONF.20/13 (April 16, 1961), and Corr. 1 (September 12, 1961), reproduced in L. LEE, VIENNA CONVENTION ON Consular RELATIONS 273-83 (1966).

13 The legal relationship of Tibet to China dates from the 13th century when Kublai Khan, a Mongol Emperor of China, donated the temporal authority to the Dalai Lamas, and continued through the Manchu dynasty and the Republican era to the 1951 Agreement of the Central People's Government and the Local Government of Tibet on Measures for the Peaceful Liberation of Tibet, translated into English in A. L. Strong, TIBetan Interviews 200-05 (1959). This has been a subject of considerable interest and controversy. Space does not permit a detailed study here except to refer readers to some of the more recent literature. See International Commission of JuRISTs, The Question of TIBET and the Rute of LAw (1959); A. LAMB, THE CHINA-INDIA Border (1964); Alexandrowicz, Conment on the Legal Position of Tibet, 5 INDIAN YEAR BOoK OF INT'L AFFAIRS 172-73 (1956) ; Green, Legal Aspects of the Sino-Indian Border Dispute, TнE CHINA Q., July-Sept. 1960, No. 3, at 43; Rubin, A Matter of Fact, 59 AM. J. INT'L I. 586 (1965); Rubin, The Sino-Indian Border Disputes, 9 INT'L \& CoMp. L.Q. 96 (1960); Sharma, The India-China Border Dispute: An Indian Perspective, 59 AM. J. InT'L L. 16 (1965); Tieh-Tseng Li, The Legal Position of Tibet, 50 AMr. J. INT'L L. 394 (1956). 
study. It may be noted that, unlike the Bolsheviks, who in 1917-1918 abrogated treaty obligations incurred by the Tsarist and Provisional Governments because of the cataclysm of "social revolution," 14 "the Central People's Government of the People's Republic of China shall examine the treaties and agreements concluded between the Kuomintang and foreign governments, and recognize, or abrogate, or revise or renew them according to their respective contents." 15 Thus, although such "unequal treaties" as the Sino-United States Treaty of Friendship, Commerce and Navigation of $1946^{16}$ have been repudiated, other "unequal treaties," including boundary treaties, have not been unilaterally abrogated. Many countries still include their pre-1949 treaties with China in their yearly publications of treaties in force. It is not certain, however, whether these treaties are still recognized as valid by the PRC. Rather than risk an outright repudiation by raising the question, the countries involved have preferred to continue the present uncertain state of affairs. On the whole, the view of Jen-min Jih-pao may be taken to reflect the official policy of the PRC: "Pending future negotiation, the status quo should be maintained." 17

As to multilateral treaties concluded under the auspices of the United Nations and signed by the Nationalist Government on Taiwan, Peking's position is uneqivocal: "An international agreement made without the participation and signature of China's representative will have no binding force whatsoever on China." 18 Recent incidents involving diplomatic personnel of the British, Netherlands, Soviet and French Embassies in Peking may reflect this position, since the 1961 Vienna Convention on Diplomatic Relations, which safeguards diplomatic privileges and immunities, was signed by the Nationalist Government, but not by Peking. ${ }^{19}$

\section{Concept of Treaties in Traditional China}

It is axiomatic that the present cannot be divorced from the past, even in a society currently undergoing a "Great Proletarian Cultural Revolution." To understand present-day Chinese treaty practice, one must first grasp the role of treaties in traditional China.

14 J. TRISKA \& R. SLUSSER, supra note 4, at 142-45.

15 See Art. 55 of the Common Program adopted in September 1949 at the Chinese People's Political Consultative Conference, translated into English in FundamentaL Legat Docunents of Communist China 34-53 (A. Blaustein ed. 1962).

1663 Stat. 1299, T.I.A.S. No. 1871 (1948). This treaty was not ratified until November 30,1948 . By then, the civil war was being fought.

17 Editorial of Jen-min Jih-pao, March 8, 1963, at 2.

18 Statement by Chou En-lai on April 10, 1960, N.Y. Times, April 11, 1960, at 7, col. 2. See also editorial of Jen-min Jih-pao, December 18, 1963, at 1.

19 See text accompanying notes 200-03 infra. 
The concept of foreign relations as dealings with foreign states based on sovereign equality did not exist in traditional China. "Foreign relations" existed only with tributary states or dependencies and involved only such matters as receiving and accommodating tributebearers, translating and transmitting their memorials to the Emperor, supervising their business dealings with Chinese merchants and arranging imperial audiences, banquets and rewards. The name of the organization in charge of such activities was itself revealing: Hui-t'ung $s s u-k u$ kuan (Residence for Envoys of the Four Tributary States); China, the Middle Kingdom, the source of civilization and center of the universe, could have no equals. The Confucian system of the family, which set out the proper roles for the superior and the inferior, the senior and the junior, also applied to the family of nations, with China as its head and the smaller states on its periphery. Annam, Burma, Korea, Siam and sometimes Japan paid homage in the form of periodic tributes. ${ }^{20}$ Indeed, the highest ideal of a Chinese, impressed upon him from childhood, was to establish order for the entire world through rectification of the mind, cultivation of the person, regulation of the family and governance of the state. ${ }^{21}$ Confucius envisaged ta-t'ung ("Universal Commonwealth") as the ultimate state of human development. ${ }^{22}$

In such a universal state, international relations, strictly speaking, did not exist. However, quasi-international relations came into existence during the Chou Dynasty (1122-256 B.C.), especially in the Ch'un Ch'iu period (722-481 B.C.). The latter part of the Chou Dynasty saw the erosion of the power of the House of Chou and the ascendency of its retainers who ruled subordinate states. During the Ch'un Ch'iu period, five such states (Ch'i, Chin, Ch'in, Ch'ü and Wu) rose to the pinnacle of power, only to fall in their turn. Like the Holy Roman Empire, the Middle Kingdom retained only its empty shell and legal fiction; actual power resided in the dependent states, whose relationship was no longer based on the rank of the retainers who governed them. In this setting, a horizontal, quasi-international law gradually developed to replace the vertical feudal order. This process was quickened as the Ch'un Ch'iu gave way to the Warring States period.

20 Thus, it was said: "Under the wide heaven, there is no land that is not the Emperor's, and within the sea-boundaries of the land, there is none who is not a subject of the Emperor." Boox of ODES, Hsiao-ya: Pei-shan, ch. II, English translation in I. C. Y. Hsu, China's ENTRANCE INTO THE Famity of Nations 6 (1960). Korean records described relations with China as sadae (serving the senior), but those with Japan as kyorin (relations with a neighbor). Id. at 4 .

21 Confuctus, The Great Learning ch. 1 (E. Pound transl. 1939).

22 The Confucian ideal of ta-t'ung states: "Wherc the 'right course' (ta-tao) reigns, there everything in the world is common property (res publica)... . this is called ta-t'ung." LI-CHI bk. 21: Li-yün. 
It was the disorder and confusion of the Ch'un Ch'iu period that moved Confucius to expound his $l i$ in his work Ch'un Ch'iu or The Spring and Autumn Annals. The concept of the Confucian $l i$, variously translated as "propriety," "ethics" or "moral rules of correct conduct and good manners," 23 dominated not only the family and society, but also the quasi-international law, which extended the concepts of $l i$ to interstate relations. ${ }^{24}$ While an exhaustive discussion of the content of $l i$ cannot be attempted here, the following illustrations of its interstate application may be given.

In one instance Confucius praised the Marquis of $\mathrm{Ch}^{\prime} \mathrm{i}$, the dominant leader of a league who had convened a congress of states to conclude a new league in 651 B.C., for thus uniting the lords by peaceful means instead of military force. The event was recorded in Tso Chuan as follows: "They assembled at K'wei-ch'iu to renew the league and to cultivate the good relations among the princes themselves; which was proper." 25

In another instance, the Duke of Hsüang and the Marquis of Ch'i tried to reconcile a conflict between the states of Ch'ü and T'an. The people of Ch'ü were unwilling to be reconciled, whereupon the Duke invaded Ch'ü and took the city of Hsiang. Tso Chuan condemned the Duke's act as not being in accord with $l i$ : "States must be reconciled by the rules of propriety, and not by disorder. To attack Ch'ü, without regulating [the difference by those rules], was creating disorder. By [sic] disorder to attempt to reconcile disorder, [it] left no room for the [proper] regulation; and without such regulation, how could any rule of propriety be carried out?" ${ }^{26}$

The state of Tsin, in refusing a peace offer from the Earl of Cheng, seized the Earl and put to death an emissary sent by the State of Cheng. Tso Chuan condemned Tsin's act as contrary to the rule that in time of hostility, any emissary must be allowed to move safely between the parties. ${ }^{27}$

Upon defeating Cheng, the powerful state of Tsin tried to impose a harsh peace settlement. Cheng protested that peace terms should be based on $l i$ and not imposed arbitrarily. Tsin conceded the propriety of this claim, acknowledging that a coerced covenant of league would

${ }^{23}$ See Lee, Chinese Communist Law: Its Background and Development, 60 MicH. L. Rev. 439, 440 (1962) ; Schwartz, On Attitudes Toward Law in China, in GoverNAIENT UNDER LAW AND THE INDIVIDUAL 28 (Amer. Council of Learned Societies ed. 1957).

24 See Iriye, The Principles of International Law in the Light of Confucian Doctrine, lectures delivered at the Hague Academy of International Law, summer 1967, to be published in the 1967 issue of Recueil de Contrs.

25 Bk. V, Duke Hsi, Yr. IX, in 5 CHINese Classics 154 (2d ed. J. Legge 1966).

$26 \mathrm{Bk}$. VII, Duke Hsüang, Yr. IV, in id. at 296.

27 Bk. VIII, Duke Ch'eng, Yr. IX, in id. at 371. 
be contrary to $l i$. Tso Chuan noted the statement from Chih Wu-tze to Hsien-tze: "We indeed have not virtue, and it is not proper to force men to covenant with us. Without propriety, how can we preside our covenants? . . . . If we are without virtue, other people will cast us off, and not Cheng only; if we can rest and be harmonious, they will come to us from a distance." Accordingly, Tsin agreed to a revision of the terms and withdrew its forces. ${ }^{28}$

Above all, $l i$ is concerned with sincerity (ch'eng) and trustworthiness (hsin), for which Western legal equivalents are "good faith" and "Pacta sunt servanda." These concepts are extensions of the Confucian concept of the proper relationship between friend and friend. Mencius said:

Between father and son, there should be affection; between sovereign and subject, there should be righteousness; between husband and wife, there should be respective duties; between the elder and the younger there should be order; between friends, there should be sincerity. ${ }^{29}$

The dominance of $l i$ in the Chinese law of treaties continued to manifest itself when China was forced to enter the modern family of nations during the 19th century. Thus, to the Chinese of the mid-19th century, the 1842 Sino-British Treaty of Nanking ${ }^{30}$ was known as the Wan-nien Ho-yüeh (the Peace Treaty of Ten Thousand Years) and was supposedly unalterable and forever valid. The Tsungli Yamen wrote in 1867: "Once an item enters into a treaty, every word of it becomes ironclad." 31 Li Hung-chang was convinced that once a treaty had been ratified, nothing further could be done about it. ${ }^{32}$ Even a monarch as xenophobic as Emperor Hsein-feng did not abrogate any treaty unilaterally. The most he did was to encourage the obstructionist tactics of his Canton viceroy, Yeh Ming-ch'en, and the Canton populace. $^{33}$

With respect to Nationalist China, it is common knowledge that it has maintained an excellent record of treaty compliance despite incessant difficulties at home. Indeed, it has justified its claim for continued representation in the United Nations, in part, upon such a record.

$28 \mathrm{Bk}$. IX, Duke Hsiang, Yr. IX, in id. at 441. 251-52.

29 Mencius, bk. III, pt. I, ch. $4, \S 8$, in 2 Chinese Classics, supra note 25 , at

3030 Britrse \& Foreign State Papers 1841-1842, at 389.

31 Ch'ou-pan I-wu Shih-mo (The Complete Account of the Management of Barbarian Affairs), in Hsu, supra note 20, at 142 .

$32 I d$.

$33 I d$. 


\section{Treaty Practice of the People's Republic of China}

\section{A. Boundary Treaties}

The importance of territorial boundaries to a nation cannot be overemphasized. Indeed, a defined territory is one of the prerequisites for statehood. In most major international issues, such as aggression, self-determination, intervention, trade and colonization, the element of territory looms large. There is nothing more likely to appeal to a nation's ego and emotion than references to "sacred soil," "motherland" or "fatherland."

Historically ill-defined boundaries often lead to international disputes or even war. The Sino-Indian border war is a case in point. A well-defined boundary, on the other hand, prevents not only border incidents resulting from honest differences of opinion, but also removes a convenient pretext for potential aggressors. It better suits the purposes of a potential aggressor to retain an unmarked or poorly defined boundary, than to have a clear-cut one. Such being the case, it is of interest to examine China's boundary policy with its neighbors.

In his statement of July 9, 1957, before the Chinese People's Congress on the Sino-Burmese border question, Premier Chou En-lai declared that it was the consistent policy of the Chinese Government to settle all unresolved issues with other counteries by peaceful negotiation on the basis of justice and reasonableness. ${ }^{34}$ It is appropriate to test this declared policy against the actual settlement of the SinoBurmese boundary issue.

Shortly after the Korean War, negotiation was initiated between China and Burma for the purpose of demarcating the boundary between the two countries. After six years of negotiation and surveying, a boundary treaty was concluded on October $1,1960,{ }^{35}$ with an exchange of notes on the same date, ${ }^{36}$ supplemented by an agreement on October 13, 1961. ${ }^{37}$ The background of these agreements is instructive in evaluating China's treaty conduct.

Since ancient times China and Burma have shared a 1,300-mile frontier, not much altered by successive changes in Burma's political status from a tributory state of China, through British domination and Japanese occupation, to eventual independence. Because of the rugged terrain, inhospitable land and malaria-infested jungles, much of the boundary had never been clearly demarcated. During World War II,

34 CHUNG-HUA JEN-RIIN KUNG-HO-KUO KUO-WU-YUAN KUNG-PAO (PRC State Council Bulletin), No. 30, at 635-39 (July 20, 1957).

359 PRC TREATY SeRIES 68.

$36 \mathrm{Id}$. at 78 .

3710 PRC TREaty Serms 52. 
the famed Burma Road became a life-line for Free China and increased contacts between Burma and China resulted. After the war, Burma became independent and inherited the undelimited boundary from Britain. Its internal situation, however, was far from stable; recurrent civil wars made it weak and easy prey for her neighbors. Confusion was compounded in 1950 when remnants of Nationalist Chinese troops, driven from mainland China, sought refuge in Burma and extralegally used Burmese territory as a base for sporadic forages into China and for illicit trade. Burma's repeated protests to the United Nations eventually led to the evacuation of the Nationalist forces under international supervision, although as of $1966,2,000$ or 3,000 Nationalists reportedly remained in Burma..$^{38}$

Against such a background, the Prime Ministers of China and Burma met in Peking on December 12, 1954, and declared it to be their policy to delimit their boundary "at an appropriate time by means of normal diplomatic channels." 39 As a result of a border incident in November, 1955, in which military forces of both countries were involved, the settlement of the entire border question acquired a sense of urgency and, in early 1956, the two countries began in earnest the work of demarcation.

By the end of 1957 the boundary was largely demarcated. Because the dispute over remaining areas involved national sensitivity on both sides, its settlement may be of interest to the outside world. The Meng-Mao triangular area (Namwan Assigned Tract), at the junction of the Namwan and the Shweli Rivers, covers 85 square miles of territory which Britain recognized as belonging to China under a boundary treaty of $1894 .{ }^{40}$ In order to safeguard a highway built to facilitate troop movement, Britain acquired jurisdiction over this territory by "perpetual lease" under an 1897 treaty. ${ }^{41}$ This leasehold was inherited by Burma upon its independence. There had never been any question as to where sovereignty resided. The PRC proposed that, since a leasehold relationship would be incompatible with friendly relations based on equality, it should be abrogated by Burma. Burma, on the other hand, suggested, in view of the practical needs of Burma, that

38 See Harrison E. Salisbury's dispatch from Rangoon, dated June 19, 1966, in N.Y. Times, June 22, 1966, at 6, col. 1 .

39 For the text of the communiqué, see 3 Chung-HuA Jen-Mmn Kung-Ho-Kuo Tuer-WaI KuAN-HSI WeN-ChIEN CHI (Collection of Foreign Relations Documents of the People's Republic of China) 216-17 (1954-55).

40 Convention between Great Britain and China, Giving Effect to Article III of the Convention of the 24th July, 1886, Relative to Burmah and Thibet, March 1, 1894, in 87 Britrsh \& Foreign State Papers 1894-1895, at 1311.

41 Article 2 of the Agreement between Great Britain and China, Modifying the Convention of March 1, 1894, Relative to Burmah and Thibet, Feb. 4, 1897, in 89 Brtise \& Foreign State Papers 1896-1897, at 25. 
China exchange this area for 73 square miles of land belonging to the Panhung and Panlao tribes, which, under an exchange of notes between China and Britain dated June 18, 1941, were given to Burma. Although China considered the "1941 line" to be an unjust legalization of Britain's conquests in the 1934 "Panhung Incident," and although the line was never actually demarcated because of the Pacific War, China nevertheless yielded to Burma's request. ${ }^{42}$

Another disputed area lay north of the High Conical Peak. This territory had remained unmarked for a long time and had been the source of many incidents, the most serious of which took place in early 1911 when Britain occupied the Hpimaw area by force. Despite British recognition on April 10, 1911, that Hpimaw, Gawlum and Kangfang (a total of 59 square miles) belonged to China, Britain continued to occupy these three villages. Burma subsequently agreed to restore these villages to China.

In the interest of efficient administration and avoidance of future disputes, it was agreed that minor adjustments of the boundary should be made so that villages should fall either entirely inside China or Burma. Such adjustments resulted in China acquiring two boundaryintersected villages (Yawng Hok and Pan Wai) and Burma acquiring four boundary-intersected villages (Umpha, Pan Kung, Pan Nawng and Pan Wai). In addition, a small adjustment in the boundary where it crosses the Taron River resulted in Burma acquiring an additional five square miles of territory, and several minor adjustments in the Shweli River area resulted in China acquiring less than two square miles. China also renounced its right of participation in mining enterprises at Lufang in Burma, which had been secured by the SinoBritish exchange of notes on June 18,1941, as being inconsistent with China's policy of opposing foreign prerogatives and respecting the sovereignty of other countries. ${ }^{43}$

Under the above exchange of lands, Burma received less territory from China than China received from Burma, although viewed in terms of population and the value of land for teak extraction, the exchange was more favorable to Burma. ${ }^{44}$ Thus ended the Herculean task of peaceably demarcating an almost impassable land. The magnitude of the accomplishment may be seen by the fact that on

42 See Article II of the Boundary Treaty Between China and Burma, Oct. 1, 1960, in 9 PRC TREATY SERIEs 68.

43 See art. IV, id.

$14 \mathrm{U} \mathrm{Nu}$, in urging unanimous Parliamentary ratification of the 1960 boundary treaty, stated: "I sincerely believe the conclusion of this Treaty to be in Burma's highest interests." Speech by Hon'ble Prime Minister Asking for the Approval of the Parliament to the Ratification of the Boundary Treaty between the Union of Burma and the People's Republic of China, Dec. 5, 1960, at 19. 
the Burmese side alone, no less than 2,400 mules and 5,600 porters were engaged in the operation. ${ }^{45}$

But has the new boundary been observed by China? A Burmese official, well-acquainted with the border situation, stated that due to the difficult terrain and sparse population, it is not always easy to ascertain whether there has been a border violation. However, to his knowledge, there has been no deliberate attempt on the part of the Chinese to enter Burmese territory. ${ }^{46}$

The theory has been advanced that China's liberal boundary policy towards Burma is for propaganda purposes and is designed to isolate India. ${ }^{47}$ However, the negotiation for the Sino-Burmese treaties antedated the Sino-Indian border dispute and the Sino-Burmese boundary settlement was not an isolated instance: China has also concluded boundary treaties with Nepal, ${ }^{48}$ Pakistan, ${ }^{49}$ Afghanistan ${ }^{50}$ and Mongolia, ${ }^{51}$ some of which also antedated the Sino-Indian dispute. Moreover, China repeatedly has called upon India to enter into negotiations for a permanent boundary treaty without any preconditions. India, on the other hand, has insisted, as a prerequisite to such negotiation, that Chinese forces be withdrawn completely from what India regards as its boundary, the validity of which (including the "McMahon Line") is open to dispute. ${ }^{.2}$

$45 I d$. at 9.

46 This official also related an observation he had made in regard to the seriousness with which Chinese boundary surveyors viewed their work. When erecting pillars as boundary markers, Chinese surveyors would engrave thereon Chinese characters on the side facing the Chinese territory, while Burmese surveyors used the Burmese language on the Burmese side. One day, because of shortage of time, the Chinese used a brush to write on the pillars, intending to do the engraving the next day. Rain washed away the painted signs at night; instead of heeding the assurance of the Burmese concerning the location of the pillars, the Chinese insisted on remeasuring that part of the line all over again. While this anecdote merely may reflect Chinese distrust of foreigners, the incident also may show meticulous care for accuracy as well as a desire to avoid future disputes.

The same Burmese official also discounted any Chinese aggressive designs on Burma, for if China were aggressively inclined, what could be a more convenient pretext than to move troops across an undelimited boundary in pursuit of or retaliation against the Nationalist Chinese forces operating on Burmese territory? To his knowledge, China has not intruded-into Burma despite many provocations.

47 See, e.g., J. RowLAND, A HISTORY OF Sino-INDIAN RELATIONS 138 (1967). See also Editorial of N.Y. Times, Feb. 2, 1960, at 34, col. 1.

48 Agreement of Márch 21, 1960, 9 PRC Treaty Series 63; Treaty of October 5, 1961, 10 PRC Treaty SerIes 45; Agreement of January 20, 1963, 12 PRC Treaty SERIES 67.

49 Agreement of March 2, 1963, 12 PRC TREATY SERIES 64; Agreement of March 26, 1965, noted in JEN-MIN SHOU-TS'E (People's Handbook) 228 (1965).

50 Treaty of November 22, 1963, 12 PRC TREATY SERIES 122; Agreement of March 24, 1965, noted in JEN-MIN SHOU-TS'E 229 (1965).

51 Treaty of December 26, 1962, 11 PRC Treaty SerIes 19; Agreement of June 30, 1964, 13 PRC Treaty Serres 78.

52 Official statements and correspondence between China and India from December 1961 to March 1962 concerning the boundary question are reproduced in 9 CHUNG-FUA JEA-MIN KUNG-HO-KUO TUEI-WAI KUAN-HSI WEN-CHIEN CHI, supra note 39, at 
Space does not permit a detailed examination of China's other boundary treaties. Suffice it to state that all these treaties appear to have been concluded on the basis of fair play and equality, and implemented through careful negotiation and surveying, with due regard to historical boundaries, custom and particular needs of the contracting parties. In the Sino-Mongolian border agreement of 1964, China reportedly gave up claims to about 25,000 square miles of territory along the frontier. ${ }^{53}$ This agreement alone covers 181 pages in the Treaty Series of the People's Republic of China, making it one of the longest treaties ever recorded. In the 1963 Protocol to the 1961 Sino-Nepalese border treaty, China and Nepal agreed to maintain the status quo so that Mount Everest, the highest peak in the world, would remain in Nepal. ${ }^{54}$ In the 1963 Sino-Pakistani border agreement concerning Sinkiang and territories under the de facto control of Pakistan, despite China's worsened relations with India, it was stipulated that the demarcation line would not prejudice India's claims or interests pending the final settlement of the Kashmir dispute. ${ }^{55}$

Where borders were already well-defined, there have been no reports of Chinese aggression. This is true even with respect to areas like Hong Kong and large parts of Soviet Asia which China considers as having been wrongfully wrought from it through "unequal treaties." Even the leased territories of Macao ${ }^{56}$ and Kowloon, ${ }^{57}$ whose existence

1-227. See, e.g., communications from the Chinese Ministry of Foreign Affairs to the Indian Embassy in Peking, dated February 26, 1962, id. at 1, and from the Indian Ministry of External Affairs to the Chinese Embassy in New Delhi, dated March 13, 1962 , id. at 14.

53 N.Y. Times, June 16, 1964, at 7, col. 6.

54 N.Y. Times, Jan. 25,1963 , at 2 , col. 7.

65 See Article 6 of the Agreement of March 2, 1963, supra note 49. Indeed, Pakistan reportedly boasted that China gave her "most of the fertile lands." Chairman Mao to Edgar Snow, in A. L. Strong, LetTers From China 124 (1963).

56 It may be noted that despite more than four centuries of Portuguese presence, Macao has never been ceded to Portugal by China. Article 2 of the Treaty of Friendship and Commerce of 1887 Between China and Portugal, in CHung-WaI T'IA0-YüER HUI-PIEN (Collection of Chinese Treaties) 412 (1964), for example, merely accorded the Portuguese the right of "yung-chii kuan-li" (permanent residence and administration); contrast this with the English text appearing in 78 BRITISH \& Foreign STATE PAPERs 1886-1887, at 521, which used the expression "perpetual occupation and government," thus favoring the Portuguese. Article 3 forbade Portugal to transfer its right to third states without China's consent. Of special interest is Article 46 which provided for automatic extensions of the treaty for ten-year periods unless "demand be made on either side within six months after the end of ten years." Id. at 529. Pursuant to this article, the treaty lapsed in 1928. China has since refused to incorporate similar provisions in subsequent treaties with Portugal. Cf. the Preliminary Treaty of Friendship and Commerce Between China and Portugal, Dec. 19, 1928 , in 130 BrITISH \& ForetgN State PAPERS 1927-1928, at 491-92, in which no mention was made of Macao.

67 The New Territories of Kowloon were leased to Great Britain for 99 years, under the Convention Respecting an Extension of Hong Kong Territory Between China and Great Britain, June 9, 1898, in 90 BrITISH \& Foreign State Papers 1897-1898, at 17. The Convention also provides for continued exercise of jurisdiction by Chinese officials in the city of Kowloon, access to the waters of Mirs Bay and Deep Bay by Chinese war vessels and the right of Chinese officials and people to cross between Kowloon and $\mathrm{H}$ sinan (San On). 
may be regarded as incompatible with the principle of the sovereign equality of states, have not been reabsorbed by China following recent incidents in both places. ${ }^{58}$ Elsewhere, Chinese "volunteers" were withdrawn from Korea in 1958, and there is no published evidence that Chinese forces have entered Viet Nam. Border relations between China and Laos, which has undergone continual civil strife, are reported by a Laotian Embassy spokesman to be normal even in areas controlled by anti-Pathet Lao forces.

\section{B. Ambassadorial Talks}

Despite United States nonrecognition of the PRC, ambassadorial talks between the two countries, begun in Geneva in mid-1955 and then

58 Incidents in Macao occurred when police were dispatched to Taipa Island to stop laborers from constructing a primary school without a permit from the Public Works Bureau. The ensuing conflict and charges of police brutality triggered rioting in Macao itself in which eight were killed, 212 injured and 61 arrested. The Government of Macao subsequently bowed to Chinese demands to punish responsible officials, to release all arrested, to proffer public apologies, to compensate the injured and families of the killed, and to bar Nationalist Chinese activities in Macao as well as to turn over alleged secret agents to mainland China. See N.Y. Times, Dec. 4, 1966 , at 1, col. 5 ; Dec. 10, 1966, at 21, col. 5; Dec. 13, 1966, at 1, col. 2; Dec. 18, 1966, at 7, col. 1 ; Dec. 23, 1966, at 3, col. 3 ; Jan. 4, 1967, at 46, col. 1 ; Jan. 30, 1967, at 2, col. 7-8.

Anti-British riots erupted in Hong Kong and Kowloon in the aftermath of labor disputes which shut down the largest cement factory, strikes by transport and electric power workers, arrests of pro-Peking newsmen and the British move to close the Kowioon border. In the most serious single border incident, five Hong Kong police were reported killed and twelve others wounded when Chinese demonstrators, aided by units of the "people's militia" (irregulars guarding frontier regions), opened fire on Hong Kong police who attempted to rout them with wooden projectiles shot from anti-riot guns and tear gas. The Chinese version, as described in a protest note delivered to the British Chargé d'Affaires in Peking, was that Hong Kong police had started the trouble by firing at Chinese demonstrators on the Chinese side of the frontier. The note stated that Chinese from the Hong Kong side had crossed into China to join a rally denouncing Britain. When they tried to return to Hong Kong, they were confronted by police "throwing tear bombs and opening fire at them, and at the same time firing at our side." The Chinese claimed that one Chinese was killed and eight were wounded. See Washington Post, July 10, 1967, at A16, col. 4 .

More serious conflicts were subsequently averted by reinforcements from regular Chinese armed units who held back the demonstrators on the Chinese side and, at one time, even fired machine-gun bursts to prevent them from crossing the border. See Washington Post, July 9, 1967, at A1, col. 5; July 10, 1967, at A16, col. 2; Aug. 25, 1967, at A18, col. 1. See also N.Y. Times, Aug. 4, 1967, at 4, col. 4; Aug. 8, 1967 , at 12, col. 1 ; Aug. $27,1967, \$ 4$, at 1, col. 4 .

It may be noted that while the British move to close the Kowloon border might have been designed to reduce border tensions in the face of anti-British riots, the effect was to worsen tensions and to raise the question of the legal status of a leased territory. Peking has taken the position that a border cannot be closed in a territory that is Chinese and, to the extent that it applies to Kowloon, the position is supportable by the 1898 Sino-British Convention Respecting an Extension of Hong Kong Territory, sippra note 57 , as well as by the view that "in strict law, these [leased territories] remain the property of the leasing state." $1 \mathrm{~L}$. OPPENHEIM, INTERNATIONAI LAW 456 (8th ed. H. Lauterpacht ed. 1955). As interpreted by Stanley Karnow, Washington Post reporter in Hong Kong, recent Chinese protests stressing China's territorial rights "are regarded as an attempt to affirm a legalistic Chinese position, rather than a threat to take over Hong Kong.". But ironically "Peking's assertions are inciting. Kwantung agitators to push their way over the frontiers, while the Chinese army is visibly working to hold them back." Washington Post, Aug. 25, 1967, at A18, col. 1. 
moved to Warsaw in 1958, have continued at intermittent intervals to this day. These talks, according to Mr. Kenneth T. Young, former Ambassador to Thailand and now President of the Asia Society, have served the useful purposes of "reducing miscalculations, clarifying intentions and explaining proposals." 50 Their genesis may be traced to the April, 1954 Geneva Conference on Korea, when Wang Ping-nan, Secretary General of the Chinese Delegation, first met with U. Alexis Johnson, Coordinator for the United States Delegation. In the same year, the United States asked the United Kingdom, which maintained a sub-Ambassadorial tie with Peking, to use Britain's good offices to obtain the release of American citizens detained in China. Peking replied by suggesting direct talks instead. This suggestion, along with Premier Chou En-lai's request at the Bandung Conference to "sit down" with the United States to discuss and negotiate the "elimination of tensions" in East Asia, led eventually to this unique diplomatic experiment in the use of direct talks as a substitute for normal relations.

Following talks on the consular level, which began in June 1954 between United States Consul General Gowen and Chinese Consul General Shen Ping, ${ }^{\mathbf{6 0}}$ the ambassadorial discussions between Wang Pingnan, Chinese Ambassador in Warsaw, and U. Alexis Johnson, United States Ambassador in Prague, ran smoothly at the outset. Agreements were soon reached on both procedural and substantive matters.

On the procedural side, Wang had originally wanted open meetings, while Johnson called for closed meetings. In the end, both sides agreed that contents of their discussion should not be divulged except by mutual agreement and that no official minutes should be prepared jointly. With but one exception, both sides appear to have adhered to this arrangement, although general statements subsequently have been made concerning the position of a country on a matter which had formed the subject of discussion at the meetings. The lone exception occurred on September 7, 1966, when Ambassador Wang Kuo-chuan, who had replaced Wang Ping-nan, summoned a press conference in Warsaw immediately following an ambassadorial talk, in order to make public a statement delivered to United States Ambassador John A. Gronouski. The press conference may have been designed to refute Soviet charges that China was plotting with the United States in Viet Nam or to quiet speculations aroused by reports that Chinese Foreign Minister Chen $\mathrm{Yi}$ had made a somewhat more moderate statement on Chinese attitudes towards the United States to a Japanese

69 Young, American Dealings with Peking, 45 ForeTgN AFFaIRs, Oct. 1966, at 76. eo See LEE, supra note 12, at 182. 
delegation headed by former Minister for Foreign Affairs Kosaka. Whatever his motivation, however, the press conference held by Ambassador Wang constituted a breach of confidence.

On the substantive side, after fourteen meetings in six weeks, the ambassadorial talks resulted in the issuance on September 10, 1955, of "agreed parallel unilateral statements," which were to resolve the problem of repatriation of civilians. ${ }^{81}$ These statements were included in the PRC Treaty Series, thus endowed with a treaty character by Peking. The United States, on the other hand, has avoided regarding them as either a treaty or an executive agreement.

In addition to twelve American civilians whose exit permits from China had been promised in a Chinese announcement of September 6, 1955, two lists subsequently were made public by the Department of State: the first containing the names of ten Americans who, according to the Department of State, would be released "soon" by the People's Republic of China, and the second containing the names of nineteen Americans who would be released "expeditiously." With respect to Chinese civilians in the United States, it was estimated that a total of 129 Chinese students and scientists were being detained in the United States during the Korean War. However, the detainers against all of them reportedly had been removed before the ambassa-

61 In view of the fact that the provisions governing the repatriation of Chinese civilians from the United States apply mutatis mutandis to the repatriation of American civilians from China (except that India was to render its good offices for China in the United States and the United Kingdom for the United States in China), only those portions of the statements dealing with the return of the Americans need be quoted:

The Ambassadors of the United States of America and the People's Republic of China have agreed to announce the measures which their respective Governments have adopted concerning the return of civilians to their respective countries. . .

With respect to Americans in the People's Republic of China, Ambassador Wang Ping-nan, on behalf of the People's Republic of China, has informed Ambassador U. Alexis Johnson:

The People's Republic of China recognizes that Americans in the People's Republic of China who desire to return to the United States are entitled to do so, and declares that it has adopted and will further adopt appropriate measures so that they can expeditiously exercise their right to return.

[2]

The Government of the United Kingdom will be invited to assist in the return to the United States of those Americans who desire to do so as follows :

a. If any American in the People's Republic of China believes that, contrary to the declared policy of the People's Republic of China, he is encountering obstruction in departure, he may so inform the office of the chargé d'affaires of the United Kingdom in the People's Republic of China and request it to make representations on his behalf to the Government of the People's Republic of China. If desired by the United States, the Government of the United Kingdom may also investigate the facts in any such case.

b. If any American in the People's Republic of China who desires to return to the United States has difficulty in paying his return ex- 
dorial talks began and at least fifty Chinese reportedly had left the United States by September 10th, while three more planned to leave by September 17 th. ${ }^{62}$

With the repatriation issue apparently settled, Wang next wished to discuss "other practical matters at issue," such as a meeting between Chou En-lai and Secretary of State John Foster Dulles, establishment of diplomatic relations and exchange of newsmen and trade. Moreover, Wang would not insist upon an American agreement to withdraw from Taiwan as a precondition to further talks. The United States, however, refused to discuss these matters until Peking released all American prisoners and agreed to a joint renunciation of the use of force in the Taiwan Strait. It was at this point. that Wang insisted that the earlier announcements covered only civilians and not "prisoners," claiming that he had never discussed or raised the issue of the repatriation of Chinese "prisoners" in the United States, but only of Chinese students, and that none of the Chinese "prisoners" in the United States had been released.

In order to counter this point, a careful census was taken of Chinese nationals in federal and state prisons and arrangements were made with federal and state authorities to commute the sentence of any Chinese prisoner who wished immediate repatriation. At the same time, Indians were sought to interview Chinese prisoners to ascertain their wishes. The census disclosed about 110 Chinese nationals in prison in the United States as of 1956.

When confronted with the above fact and an offer to exchange Chinese for American prisoners, Wang alleged the existence of a plot to inflict a propaganda defeat on Peking, comparable to the Chinese prisoner-of-war issue in Korea, and that only those Chinese prisoners who did not want to return to China would be included in the list of prisoners. Subsequently, the American Red Cross interviewed some ninety Chinese prisoners. Among these, six reportedly indicated their desire to be repatriated, although five later changed their minds and only one reportedly returned to China.

The United States view was clearly that prisoners were to be included among repatriates under the "unilateral but identical" announcements. Ambassador Johnson stated that there was no doubt in his mind that both he and Ambassador Wang were referring to

penses, the Government of the United Kingdom may render him financial assistance needed to permit his return.

The Government of the People's Republic of China will give wide publicity to the foregoing arrangements and the office of the chargé d'affaires of the United Kingdom in the People's Republic of China may also do so.

32 U.S. Dep't State BULr. 456 (1955) ; 4 PRC Treaty SeRIes 1.

62 N.Y. Times, Sept. 11, 1955, at 3, col. 3-4, 6 . 
"prisoners" in their discussion of the repatriation issue, noting also that in the texts of the announcements, the generic terms "civilians" and "Americans" were used without any exception as to prisoners. ${ }^{63}$ Kenneth Young ${ }^{64}$ describes the ambassadorial negotiation as one concerning "the repatriation of some 40 Americans incarcerated in Chinese Communist jails," and the ensuing agreement as one "on repatriation of prisoners." On the other hand, the United States position that the repatriation agreement covered "prisoners" appears to be undercut by its own failure to initiate steps to repatriate Chinese prisoners (in contradistinction to students and scientists) until the dispute came to the fore at a much later date.

There remains the question whether Peking had agreed to the two lists of names of those Americans to be released "soon" and those to be released "expeditiously," as published by the Department of State on September 10, 1955. The second list specifically included the names of people still in Chinese prisons today, such as John T. Downey and Richard Fecteau. If Peking had indeed agreed to the content of this list, negotiations for the immediate release of remaining American prisoners profitably might be reopened on the basis of that agreement, rather than on the ground that "prisoners" as such were the objects of the "unilateral but identical" announcements.

It may be noted also that henceforth the "unilateral but identical" formula may not, as a general rule, be acceptable to Peking. Thus, in discussing the question of exchanging correspondents with the United States, Peking has said:

The American draft takes the form of statements to be issued by the ambassadors of the two countries separately. We remember that the agreement of the two sides on the return of civilians to their countries also took this form. But the fact that the U.S. side has so far failed to seriously implement the agreement shows that this form does not have enough binding force on the U.S. side. To prevent the U.S. side from again violating the agreement, the Chinese side resolutely maintains that all agreements between the two sides must take the form of joint announcements of both sides, and no longer take that of statements issued by two sides separately. ${ }^{65}$ 1966.

63 Interview With U. Alexis Johnson, U.S. Ambassador, in Tokyo, Japan, Dec.

64 Young, supra note 59.

65 Pering Review, Sept. 14, 1960, No. 37, at 30.

An exception may be noted, however, when Peking suggested recourse to parallel unilateral declarations by both sides (perhaps as an interim measure) to ban the use of nuclear weapons. This followed Washington's rejection of an earlier proposal to conclude a treaty to this end after Peking had successfully conducted an atomic test in October, 1964. Peking Review, Jan. 1, 1965, No. 1, at 20. See also M. Halperin \& D. Perkings, Communist China and Aras Control 127-28 (1965). 
In any event, this whole episode may serve to underscore the importance in any future negotiations with China of arriving at a text free from all ambiguity, even if this can only be accomplished by expending a great deal of time.

\section{Korean Armistice Agreement}

It is not the purpose of the present study to trace the political and military developments in connection with the Korean War, to deal with such legal issues as the validity, binding force and compliance records of the Cairo Declaration of December 1943, the Potsdam Declaration of July 1945 and the various United Nations resolutions concerning Korea. Attention is focused rather on the record of Chinese compliance with the Armistice Agreement, signed on July 27, 1953, between the Commander-in-Chief of the United Nations Command (UNC) on the one hand, and the Supreme Commander of the Korean People's Army (KPA) and the Commander of the Chinese People's Volunteers (CPV) on the other. ${ }^{68}$ An examination of this record yields valuable insight into Chinese treaty practice in times of stress.

The present study is the first ever undertaken of the records of the Military Armistice Commission (MAC) by non-military personnel in the West. One reason for the previous lack of such a study is that, although the "Unified Command" was created pursuant to a Security Council resolution of July 7, 1950, under which the Command would report to the Security Council "as appropriate," there has been no report to the Council since the conclusion of the Armistice in 1953. ${ }^{\circ 7}$ The present study was undertaken in Seoul, Korea, where a complete record of Armistice compliance and complaints of violations is kept, and was supplemented by interviews with officials, including those of the Neutral Nations Supervisory Commission.

Four major items, each of which will be discussed below, were covered in the Armistice Agreement: the establishment of a Military Demarcation Line and a Demilitarized Zone (Article I); Concrete Arrangements for Cease-fire and Armistice (Article II); Arrangements Relating to Prisoners of War (Article III) ; and Recommendations to the Governments Concerned (Article IV).

Article I provides for the fixing of a Military Demarcation Line (MDL) and mutual withdrawal for a distance of two kilometers from the Line so as to separate the opposing forces by a Demilitarized Zone

661953 YeARBoOK of THE UNITED Nations 136-46. The Agreement is included in 2 PRC TREATY SERIES 382 as an addendum, thus indicating its semi-official status. The United States, on the other hand, includes it in 4 U.S.T. 234, T.I.A.S. No. 2782 (1953).

67 Press Service OPI Briefing, United Nations, Nov. 4, 1966. 
(DMZ) which acts as a buffer preventing the occurrence of incidents which might lead to a resumption of hostilities. The number of persons, military and civilian, permitted to enter the Zone from each side for purposes of civil administration and relief shall not exceed 1,000 at any one time. Civil administration and relief in the northern half of the Zone shall be the joint responsibility of KPA/CPV, while that in the southern half shall be the responsibility of UNC. "No person, military or civilian, shall be permitted to enter the Demilitarized Zone except persons concerned with the conduct of civil administration and relief and persons specifically authorized to enter by the Military Armistice Commission." Nor shall any one be permitted to cross the Line without specific authorization of the Commission. "Neither side shall exercise any hostile act within, from, or against the Demilitarized Zone." Complete freedom of movement, however, is assured to the "Military Armistice Commission, its assistants, its Joint Observer Teams with their assistants, the Neutral Nations Supervisory Commission . . . , its assistants, its Neutral Nations Inspection Teams with their assistants, and of any other persons, materials, and equipment specifically authorized to enter the Demilitarized Zone by the Military Armistice Commission." Civil police of both sides may not carry heavy or automatic weapons, and must wear proper identification.

In actual practice, a clear distinction between "civil" and "military" personnel is well-nigh impossible, automatic weapons can easily be concealed, collusion with civil police on one's own side of the DMZ can be taken for granted and the crossing of the MDL on the ground and in the air and sea, whether for espionage, sabotage or other purposes, has been recurrent. In the year 1966 alone, for example, the UNC announced that 24 of its soldiers were killed on 14 separate occasions by "armed killer bandits" from the other side, the single largest incident (in which six Americans and one South Korean lost their lives) coinciding with President Johnson's visit to South Korea. The KPA/CPV side, on the other hand, accused the UNC of 8,460 violations of the Armistice Agreement during the twelve-month period, although 8,218-or 97 per cent-involved routine administrative matters, including 7,529 cases of alleged improper identification (e.g., armbands) of UNC personnel in the DMZ. ${ }^{68}$

Chinese compliance with Article $I$ is of direct relevance to the present study. A thorough examination was undertaken of the files of MAC prior to October 26, 1958, the date Chinese forces were withdrawn from Korea, revealing that only one violation specifically involving Chinese personnel had been charged by the UNC at MAC.

68 Year end statement by UNC at 237th MAC meeting in Panmunjom, given in briefing by UNC Rear in Camp Zama, Japan, Dec., 1966. 
In this case, the UNC alleged that two unarmed men in the vicinity of Koyangdae crossed the MDL at 8 a.m., August 6, 1953, to a distance of 600 meters south of the Line. The two men engaged in conversation with members of the UNC, one stating that he was a Korean who had lived in Manchuria for a long time before being taken into the army, and the other stating that he was Chinese. When asked why they had crossed the Line, they said they had come to pick up communication wire. To the question whether they were from the Third Regiment, First Division, First Army, they replied, "yes." They returned to their side of the line at 12:30 p.m. the same day. ${ }^{69}$ At the MAC meeting, the KPA/CPV side readily admitted that its personnel, in the course of clearing hazards in DMZ, had crossed the MDL by mistake, and stated: "We express regret for this incident." 70

The above discussion, of course, cannot be taken to mean that there was only one Chinese violation of Article I; other violations well might have gone undetected or have been taken up at the Secretaries meetings, which handle only routine administrative matters, not serious violations of the Armistice Agreement. It is noteworthy, however, that through the years, only one incident specifically involving Chinese personnel was serious enough to reach the MAC, and the Chinese readily admitted and expressed regret for the incident.

Article II not only calls for a cease-fire and a mutual withdrawal of forces from the $\mathrm{DMZ}$, but also specifies that, pending a political settlement, the relative military combat power of the two opposing sides must be maintained at the same level as on July 27, 1953. To ensure this, personnel were only to be exchanged or rotated man-forman, and weapons were only to be exchanged piece-for-piece and were to be of the same type and capability as when the agreement was signed. No additional weapons or new types of weapons were to be brought into Korea by either side. For the purpose of supervising the implementation of this provision and settling disputes which might arise, the MAC was established to be composed of ten senior officers, five appointed by the UNC and five appointed jointly by the $\mathrm{KPA} / \mathrm{CPV}$. The MAC was to be assisted in its tasks by: (a) Joint Observer Teams, composed of officers of equal numbers from both sides, to investigate alleged violations of the Agreement occurring in the DMZ or in the Han River Estuary, and (b) the Neutral Nations Supervisory Commission (NNSC) composed of officers from Sweden, Switzerland, Poland and Czechoslovakia, whose functions were to carry out supervision, observation, inspection and investigation outside the $D M Z$ or at the request of the MAC. The NNSC was in turn to be

09 Record of the 9th meeting of MAC, Aug. 8, 1953.

70 Id. 
assisted by Neutral Nations Inspection Teams (NNIT), ten of which were to be stationed at five ports of entry under the military control of the UNC and five under the military control of the KPA/CPV. Officers of the teams were to be accorded full convenience of movement within the areas and over agreed upon routes of communication.

Despite this elaborate machinery, disputes arose almost immediately after the signing of the Armistice Agreement. Some of these may have been due to honest differences of opinion in construing the language of the Agreement. For example, does the term "combat aircraft" include a "trainer" or "reconnaissance plane"? Do spare parts which could be assembled into "combat aircraft, armored vehicles, weapons, and ammunition" fall under the restrictions of Article II?

There were, however, clear violations by both sides. Thus, contrary to Paragraph 13(d) of the Agreement, which requires both sides to report incoming and outgoing combat aircraft, the KPA/CPV has not submitted a single such report. Upon complaint by the UNC to NNSC on October 12, 1953, a Mobile Inspection Team was dispatched to conduct an investigation of an airfield near Uiju where newly arrived aircraft were reportedly located. The UNC supplied the following version of the investigation: the Team was at the airfield for only 3 hours and 55 minutes during the first six days of investigation. Twenty-five minutes were spent in a moving vehicle, guided by the airfield commander, while the remaining time was spent in discussion with the commander before and after the conducted tour. Although the Team reported that no aircraft crates were observed, there were numerous aircraft present which they were not permitted to inspect and for which the airfield commander refused to make any satisfactory accounting. No permission was given to inspect the northern and southern sides of the airfield, nor the various means by which the crates or craft might have been introduced, nor the areas where the alleged crates might have been hidden. Further inspection, proposed by the Swiss and Swedish members of the Team, was voted down by the Polish and Czechoslovak members. Not until the seventh day after its arrival was the Team permitted to make another inspection under the guidance of the airfield commander. Again, no evidence of crates was found. ${ }^{71}$

It was ostensibly this type of violation by the KPA/CPV which prompted the UNC to announce, at the 75th MAC meeting on June 21, 1957, the temporary suspension of the operation of Paragraph 13(d) of the Agreement until such time as relative military balance had been restored and the other side, by its action, had demonstrated its

71 Record of the 38th meeting of MAC, March 9, 1954; Record of the 60th meeting of MAC, July 5, 1955. 
willingness to comply with said provision. Since then, the UNC has refused to report the movement of any combat material going in and out of Korea.

The compliance record of the UNC actually was not above reproach, even before it unilaterally suspended the operation of Paragraph 13(d). Despite Paragraph 13(j) of the Agreement, which grants diplomatic privileges and immunities to NNSC personnel, there were many incidents of mistreatment of neutral nations personnel in South Korea. ${ }^{72}$ More seriously, NNIT personnel were prevented from boarding American vessels to inspect boxes reportedly containing combat material, ${ }^{73}$ from carrying out inspection work in the harbor of Inchon ${ }^{74}$ and from conducting spot-check inspections in Pusan on August 20, 1955, and in Taegu on August 8, 1955, except by helicopter. ${ }^{75}$ These restrictions occurred despite: (a) Preliminary Instruction No. 21 of the NNSC which states that "the team has to insist upon boarding a ship only in case its supervision and inspection cannot be carried out properly by any other means"; (b) Paragraph $13(\mathrm{~g})$ of the Armistice Agreement which affords to NNIT personnel "all possible assistance and co-operation" as well as "full convenience of movement" between the headquarters of NNSC and the ports of entry or "the places where violations of this Armistice Agreement have been reported to have occurred."

There were also instances of incorrect reporting or omissions of incoming and outgoing material. On September 4, 1953, the NNIT in Pusan uncovered 106 4.2-caliber mortars which the UNC introduced under the guise of "Supplies for PX." The UNC report of December 9, 1953 did not contain any figure for incoming combat aircraft, although reports of the NNIT stated that at least nine craft were introduced in the same period.

At the 70th MAC meeting, on May 31, 1956, the UNC announced that because of obstructions and violations by the KPA/CPV and the conduct of the Czechoslovak and Polish members of the NNSC and the NNIT, it had decided to suspend provisionally performance of its part of those provisions of the Armistice Agreement governing operations by the NNSC and NNIT in the area under the control of

72 Letter from NNSC to MAC, Sept. 8, 1953, discussed at the 18th meeting of MAC, September 9, 1953. See also Record of the 41st meeting of MAC, April 20, 1954; Record of the 45th meeting of MAC, August 3, 1954; Letter from NNSC to MAC, Aug. 10, 1955.

73 Letter from NNSC to MAC, Sept. 17, 1953, concerning inability to board the steamship "Morning Light" in Pusan; Report of NNIT No. 8 (Pusan), cited in Letter from NNSC to MAC, Oct. 10, 1953, and discussed at the 26th meeting of MAC, Oct. 20, 1953, and at the 41st meeting of MAC, April 20, 1954.

74 Record of the 41st meeting of MAC, April 20, 1954.

75 Report of NNI'T, Aug. 20, 1955, discussed at the 69th meeting of MAC, Feb. 25, 1956. 
UNC. Consequently, all NNSC and NNIT personnel were withdrawn from the territory under the military control of the UNC to the Demilitarized Zone by June 9, 1956 . This was followed by similar withdrawal from the north by June 12, 1956.

In evaluating Chinese performance under Article II of the Armistice Agreement, it should be noted that, although there is evidence that new aircraft have been introduced into North Korea since the Armistice, their origin has not been determined. There have been unsubstantiated rumors that these new MIGs came from the Soviet Union, rather than China. The question still remains as to Chinese responsibility under the Agreement in view of the existence of a joint KPA/CPV undertaking to prohibit the introduction of these MIGs and to report any such introduction to the MAC. The exact extent of such responsibility hinges, in turn, upon the question whether, in this instance, North Korea has acted as an agent for the Chinese, as an equal partner with China or in disregard of Chinese wishes for compliance. As of this writing, information is still insufficient to clarify the above picture.

The question of prisoner repatriation was governed by Article III as well as by the Terms of Reference for Neutral Nations Repatriation Commission, which was signed on June 8, 1953, and incorporated into the Armistice Agreement. The principle against forcible repatriation of prisoners was adopted, ${ }^{76}$ and a Neutral Nations Repatriation Commission (NNRC), composed of Sweden, Switzerland, Poland, Czechoslovakia and India (Chairman) was established to oversee the prisoners' custody, repatriation and settlement.

The repatriation issue was a complex one, involving the ascertainment of a prisoner's state of mind and intent. Unfortunately, prisoners became pawns in the grip of power politics, and there were many instances of bad faith, coercion, brutality, unfair pressure and terrorizing by secret agents planted among prisoners. The most serious incident involved the unilateral mass release of 27,000 North Korean prisoners by President Syngman Rhee on June 18, 1953, in violation of the Terms of Reference for NNRC ${ }^{77}$ _an action which brought immediate

76 The principle had been strenuously opposed by the KPA/CPV, resulting in a delay of almost two years in the signing of the Armistice Agreement. The KPA/CPV cited the following provisions in the 1949 Geneva Convention relative to the Treatment of Prisoners of War, 75 U.N.T.S. 135, as evidence that international law was opposed to the "voluntary repatriation" principle:

Article 7. Prisoners of war may in no circumstances renounce in part or in entirety the rights secured to them by the present Convention. . . .

Article 118. Prisoners of war shall be released and repatriated without delay after the cessation of active hostilities. . .

The UNC argued that the spirit of the Geneva Convention was to protect the best interests of prisoners. See C. Jox, How Communists Negotiate 153 (1955). $7 \tau$ Paragraph 1 of the Terms of Reference, 1953 Yearbook of THE UNITEd NATIONS 144 , provides in part: 
repudiation by President Eisenhower, Secretary of State Dulles and the UNC.

Although space does not permit a discussion of other incidents, on the whole, more violations by the UNC than by the KPA/CPV were uncovered or confirmed by NNRC personnel and reported at MAC meetings. ${ }^{78}$ The following reasons may be advanced: (a) there were more prisoners held by the UNC than by the KPA/CPV; (b) President Rhee was known to be unsympathetic with many of the UNC objectives and had thus often pursued an independent course of action; (c) the UNC may have allowed the NNRC more freedom to seek out and investigate violations than did the KPA/CPV.

A discussion of the repatriation issue is not complete without a reference to American airmen and civilians allegedly shot down over Manchuria, China, during the Korean War. The dispute centered

In order to ensure that all prisoners of war have the opportunity to exercise their right to be repatriated following an armistice, Sweden, Switzerland, Poland, Czechoslovakia and India shall each be requested by both sides to appoint a member to a Neutral Nations Repatriation Commission which shall be established to take custody in Korea of those prisoners of war who, while in the custody of the detaining powers, have not exercised their right to be repatriated. . . .

Paragraph 4 provides:

All prisoners of war who have not exercised their right of repatriation following the effective date of the Armistice Agreement shall be released from the military control and from the custody of the detaining side as soon as practicable, and, in all cases, within sixty (60) days subsequent to the effective date of the Armistice Agreement to the Neutral Nations RepatriId. ation Commission at locations in Korea to be designated by the detaining side.

78 While there was no mention of any Chinese or North Korean violation of the prisoners repatriation provisions of the Armistice Agreement in the NNSC or NNRC reports as discussed at the MAC meetings, the following references to UNC violations, in addition to Rhee's unilateral release of 27,000 prisoners, may be noted: At the 28 th meeting of MAC held on November 18, 1953, reference was made to the investigation conducted by Neutral Nations Mobile Teams in POW camps of the UNC at Koje-do, Yongdong-po and the Imjin River Bridge, which confirmed UNC vioiations of the Military Armistice Agreement and the Agreement for the Operation of the Joint Red Cross Teams; at the 29th meeting of MAC on November 21, 1953, a formal report by the NNRC, dated November 15, was cited to show that the Indian Custodian Force on November 7 th had intercepted a military radio set hidden in food supplies being sent into the Tongjang-ni POW camp. The Indian Force on the same day also discovered that nurses of the 64th Field Hospital of the U.S. Army located in the same POW camp communicated with "secret agents" in compound 49 nearby and exchanged letters, one of which was intercepted by a sentry on duty. The NNRC stated that it "considers the facts deriving from the report mentioned above as an abuse of providing medical support by the UNC and as a violation of the Terms of Reference for NNRC," and requested that the UNC take "immediate measures to prevent any further illegal activities of personnel employed in the 64th Field Hospital."

At the 31st meeting of MAC on December 1, 1953, a formal notification by NNRC dated November 24th stated that on November 8th the Indian Custodian Force had intercepted a letter from a secret agent who was attempting to enter the Tongjang-ni POW camp. The letter contained directives from President Rhee and the Nationalist Chinese Embassy in Pusan stating that "explanations should not be attended"- a reference to the efforts of representatives of other nations to confer with soldiers held prisoner who refused repatriation. It promised that the Army of the Republic of Korea (ROK) would advance and attack the Indian forces, if the latter attempted to coerce prisoners into attending the explanations. 
on the question whether these men should be considered "prisoners of war" in the context of the Armistice Agreement and hence entitled to repatriation. The dispute eventually led to a personal visit to Peking by the late Secretary General of the United Nations, Dag Hammarskjöld. Subsequently, military personnel were released, without any reference to their rights under the Armistice Agreement. Some civilian personnel, however, remain in Chinese prisons to this day.

Article IV of the Armistice Agreement provides that the military commanders of both sides shall recommend to the governments concerned that, within three months after the coming into force of the Agreement, "a political conference of a higher level of both sides be held by representatives appointed respectively to settle through negotiation the questions of the withdrawal of all foreign forces from Korea, the peaceful settlement of the Korean question, etc." Inasmuch as the specific obligation only consisted of making the recommendations, without regard to their actual implementation, both sides may be said to have complied with Article IV upon signing the Armistice Agreement.

It may be noted that the proposed conference was subsequently held in April 1954 in Geneva without any conclusive result. On April 9, 1956, the Governments of the PRC and the Democratic People's Republic of Korea proposed the convening of a conference of countries concerned to negotiate the withdrawal of all foreign troops from Korea and the peaceful unification and demilitarization of Korea, but the proposal was rejected after a meeting of the representatives of sixteen nations at the Department of State. The General Headquarters of CPV nevertheless announced, on February 20, 1958, that it had decided to withdraw its forces completely from Korea by stages before the end of 1958, with the first stage to be completed before April 30, 1958. On March 12, 1958, the KPA/CPV side requested the NNSC to supervise and inspect the first stage withdrawal of 80,000 men, scheduled to take place between March 15 and April 30, 1958, through the port of Sinuiju. At the meeting of March 14, 1958, in Panmunjom, the request was welcomed by the Polish and Czechoslovak members of the NNSC but was rejected after objections by the Swedish and Swiss members on the ground that such activities lay outside the legal competence of the NNSC. At the 88th meeting of MAC held on October 27, 1958, the KPA/CPV announced completion of the withdrawal by CPV in three stages during the period of March 15 to October 26, 1958. As far as can be ascertained from the records of the MAC, there is no indication that the CPV has not completely withdrawn its forces from Korea or has subsequently re-entered Korea.

A few general observations may be appropriate before concluding the present discussion. Contrary to the oft-repeated view that the 
Korean Armistice Agreement has been violated continually by the Chinese, the Chinese policy appears to be one of careful observance of the Agreement. Despite the fact that the NNSC has often been paralyzed as a result of disagreements between the Swedes and Swiss, on the one side, and the Poles and Czechs on the other, the Chinese have continued to emphasize its role. The Chinese attitude may be seen from the following incident. In nearly identical notes dated January 27, 1955, Sweden and Switzerland requested Peking's approval for a reduction of their personnel in the NNSC on the ground of financial difficulties. Peking's reply stressed the important contribution of the NNSC in maintaining peace in Korea and refused to consider the possibility of terminating its activities, based as they were on the Armistice Agreement. However, since the Agreement did not specify the number of personnel to be maintained by the NNSC, and in view of the financial burden imposed upon the Swedish and Swiss Governments, the PRC would not object to the proposed reduction of personnel so long as NNSC activities would not be adversely affected. ${ }^{\text {9 }}$ In line with this emphasis on the neutral nations' peace-keeping role in Korea, the PRC seriously protested the UNC's suspension of neutral nations' activities in South Korea, eviction of NNSC and NNIT personnel to the DMZ and refusal to report on the movements of combat material in Korea, as required by Paragraph 13(d) of the Armistice Agreement.

To summarize: in the only known incident in which unarmed Chinese crossed the MDL in violation of the Armistice Agreement, Chinese acknowledgment and expressions of regret were swiftly made; restrictions on neutral personnel movement and communication in North Korea appears to be the sole responsibility of the North Korean authorities, and in at least one instance, the record shows that the Chinese have interceded on behalf of freedom of movement for Swedish personnel; the origin of new MIGs introduced into North Korea since the Armistice cannot be ascertained with any finality, and there are indications that they came from the Soviet Union, rather than China; although CPV insistence on a principle of forcible repatriation of prisoners accounted for a long delay in the signing of the Armistice Agreement, once the principle was agreed to, the PRC appears to have complied; and when the simultaneous withdrawal of all foreign troops from Korea and peaceful unification of Korea through free elections under the supervision of neutral nations could not be realized, the PRC unilaterally withdrew its forces from Korea, which, in effect,

${ }^{79}$ See Chinese memoranda to the Swedish and Swiss diplomatic missions, Feb. 17, 1955, reproduced in 3 CHUNG-HUA JEN-MIN KUNG-HO-KUO TUEI-WAI KUAN-HSI WEN-CHIEN CEI, supra note 39, at 236. 
complied with important parts of both Article IV of the Armistice Agreement and the General Assembly Resolution of February 1, 1951.

Lest the PRC be involved in another Korean War by a North Korean attempt to reunify Korea by force, the 1961 Treaty of Friendship, Co-operation and Mutual Assistance with North Korea provides that:

The Contracting Parties hold that the unification of Korea must be realized along peaceful and democratic lines and that such a solution accords exactly with the national interests of the Korean people and the aim of preserving peace in the Far East. ${ }^{80}$

Since the summer of 1966, the PRC's military disengagement has apparently been extended to the conference table: its seats at the MAC in Panmunjom have remained unoccupied; simultaneous interpretation into Chinese during the Secretaries' meetings has been discontinued; and only a few minor officials now sit, at a respectable distance from the Koreans and Americans, during Panmunjom conferences.

\section{Fisheries Agreements}

Among the most unique of all international agreements are the various Sino-Japanese fisheries agreements concluded since 1955. These agreements, although entered into by fisheries associations of the two countries, regulate matters traditionally reserved to sovereign states, such as the delineation of fishing zones, the fixing of the number of fishing vessels permitted to enter such zones by each party and the right to provisions and shelter in ports. Hence, prior governmental approval, if not actual formulation, of the contents of the agreements may well be presumed. While the Japanese Foreign Office does not accord official standing to these agreements, the PRC has included them in its Treaty Series, thus imbuing them with a treaty-like character.

A study of the background and development of the fisheries relations between the two countries sheds interesting light not only on the interplay of political, economic and legal forces, but also on

80 Treaty of Friendship, Co-operation, and Mutual Assistance Between China and North Korea, 1961, art. 6, in PRC GoodwIL TREATIEs 45-50. This article recalls the Chiang-Dulles joint communique of October 23,1958 , which reads in part:

The Government of the Republic of China considers that the restoration of freedom to its people on the mainland is its sacred mission. It believes that the foundation of this mission resides in the minds and the hearts of the Chinese people and that the principal means of successfully achieving its mission is the implementation of Dr. Sun Yatsen's three people's principles (nationalism, democracy and social well-being) and not the use of force. (Emphasis added.) See 39 U.S. Def't of State, Bulz. No. 1011, Pub. No. 6724, at 721-22 (Nov. 10, 1958). 
Chinese compliance with respect to agreements concluded by parties of unequal strength and primarily for the benefit of the weaker partyweaker because it lacks effective government protection in the face of Japan's nonrecognition policy towards Peking.

With respect to the right and duty of states to negotiate and conclude fisheries agreements, the 1958 Geneva Convention on Fishing and Conservation of the Living Resources of the High Seas provides: ${ }^{81}$

Article 4. If the nationals of two or more States are engaged in fishing the same stock or stocks of fish or other living marine resources in any area or areas of the high seas, these States shall, at the request of any of them, enter into negotiations with a view to prescribing by agreement for their nationals the necessary measures for the conservation of the living resources affected. . . .

Article 6. (1) A coastal State has a special interest in the maintenance of the productivity of the living resources in any area of the high seas adjacent to its territorial sea.

(2) A coastal State is entitled to take part on an equal footing in any system of research and regulation for purpose of conservation of the living resources of the high seas in that area, even though its nationals do not carry on fishing there.

(3) A State whose nationals are engaged in fishing in any area of the high seas adjacent to the territorial sea of a State shall, at the request of that coastal State, enter into negotiations with a view to prescribing by agreement the measures necessary for the conservation of the living resources of the high seas in that area. . . .

Article 7 enables a coastal state to take unilateral measures of conservation upon fulfilling certain requirements, if negotiations with other states have not led to an agreement within six months.

It may be noted that fisheries agreements are usually concluded between states which have recognized each other. ${ }^{82}$ Since the PRC

812 U.N. Conference on the LAW of the SeA, OfFicial Record 139-41, U.N. Doc. A/CONF. 13/L.54 (1958).

82 This is necessarily implied in articles 4 and 6 of the 1958 Geneva Convention, supra note 81. Nonrecognition "results in treating as non-existent the legislative, judicial and administrative acts of the State whose government has been refused recognition; it entails in many cases the suspension of the operation of treaties concluded by former governments." H. LAUTERPACHT, RECOGNITTON IN INTERNATIONAL LAw 4-5 (1947). Even though conclusion of a treaty does not necessarily imply recognition, id. at 375; T. CHEN, ThE INTERAATIONAL LAW OF RECOGNITION 193 (1951), an unrecognized government is not obliged to enter into a treaty intended primarily for the benefit of the state which denies it recognition. It is for that state to weigh whether the price paid for withholding recognition is unduly high, and must reap the consequences accordingly. Thus, despite the urgent need for a fisheries 
has not been recognized by Japan and has not signed the 1958 Geneva Convention, there was no legal duty on its part to conclude a fisheries agreement with Japan..$^{83}$

Just as ambassadorial talks were used as a substitute for normal diplomatic channels between Washington and Peking, agreements between fisheries associations were utilized to take the place of fisheries treaties between Japan and the PRC. While the agreements are consistent with the Bandung spirit of friendly relations and peaceful coexistence, Japan had an additional and more important reason for seeking a fisheries agreement. Between 1950 and 1954, a period of tension heightened by the Korean War and military activities in the Taiwan Strait, the PRC detained 158 Japanese fishing vessels and 1,909 crewmen under the charges of espionage and other illegal activities. Fifty-four vessels and all the crewmen (except 17 who died during captivity) were later returned to Japan. However, the desire to obtain the release of the remaining vessels and to prevent future incidents, as well as the need to regularize fishing activities off the China coast in the face of growing Chinese interest in developing their own fisheries resources, led to the conclusion of the fisheries agreement on April 15, 1955. This Agreement, between the Chinese Fisheries Association (CFA) and the Japan-China Fisheries Association (JCFA), concerning Fisheries on the Yellow Sea and the Eastern Sea, contained the following major provisions: ${ }^{84}$

(a) Six fishing zones were delineated in which fishing during specified seasons by a maximum number of vessels of each party was permitted. (Article 2.) In view of China's claim of a 12-mile terri-

agreement between Japan and South Korea (which has reportedly seized 146 Japanese fishing vessels and 1,776 crewmen for alleged violations of the "Rhee Line," G. Borgstrom, JAPAN's WORLD SUCCESS IN FISHING 30 (1964)), a fisheries agreement was not concluded until December, 1965, immediately following the establishment of diplomatic relations between the two countries.

83 The importance of fisheries industries to Japan cannot be overemphasized. Its marine products, for example, furnish almost two-thirds of the proteins consumed by Japanese people. NIPPON: A CHARTER SURVEY OF JAPAN 136 (1966). As of September, 1966, the number of people employed in fisheries, agriculture and related jobs numbered 620,000 (of whom 480,000 are males), out of a total of $49,180,000$ (of whom $29,390,000$ are males) employed in all industries. JAPAN BUreau of Statistics, OfFice of the Prime Minister, Monthly Statistics of JAPAN, No. 65, at 8 (Nov., 1966). Yet, although it is the world's leading fishing nation, Japan, to meet its growing demand, must still import fish not only from neighboring. South Korea, Russia and Taiwan, but from more remote nations like Peru, Mexico, Spain and Australia as well. Japanese fish imports amounted to $\$ 7,700,000$ in 1959 , but jumped to $\$ 160,000,000$ in 1966 and are expected to reach $\$ 200,000,000$ in 1967. Asahi Evening News, Feb. 3, 1967, at 7, col. 3. At the same time, however, Japan's own fish catches have leveled off sharply, due to attrition of marine resources, the gradual tightening of controls imposed by other countries on Japan's pelagic fishery and pollution of fishing grounds by waterfront industrial plants. Its total catch in 1965 was $6,880,000$ tons, or only 20,000 tons more than in 1962. Id.; NIPPON: A CharTER SuRveY OF JAPAN 136 (1966).

844 PRC Treaty Series 265. 
torial limit, these zones begin from 13 to 80 miles, or an average of 50-60 miles, off the coast of China.

(b) In the interest of safety and orderliness at sea, in addition to international custom on navigation, vessels of both parties must observe specified rules concerning identification, signaling, anchoring, netting and the keeping of minimum distance between vessels and maximum speed. (Article 3.)

(c) Both parties must render mutual assistance in case of untoward incidents, natural disaster or serious injury or illness of crewmen. (Article 4(1).)

(d) In case of emergency (defined as serious injury other than epidemics, serious damage to engines or ship's body, serious leaking in ship's hull and a hurricane or storm), Chinese vessels may enter three designated ports in Japan and Japanese vessels may enter three designated ports in China for limited duration upon notification to appropriate local authorities and compliance with certain rules. Among the rules is one requiring compliance with local laws prohibiting use of wireless communication, disembarkation without permission and investigation or recording of atmospheric conditions, depth of waters or anything unconnected with fishing activities. Local fisheries associations or other appropriate bodies shall assist these vessels, to the best of their ability, in their requests for food, water, medicine or other necessities. (Article 4(2).)

(e) In the interests of conservation and development of fishing resources, the two associations shall exchange information and materials on research, statistics and technical equipment. (Article 5.)

(f) Upon receiving evidence that the number of vessels in a fishing zone exceeds that allotted to a party under the present agreement, vessels of the other party shall report such violation to their own association which shall forward such information to the other association. The latter shall take appropriate measures against the delinquent vessels and report back on measures taken. (Article 6(1).)

(g) Disputes involving vessels of both parties should, if at all possible, be settled on the spot. Only after the failure of such a settlement should the disputes be referred to their respective associations for resolution. (Article 6(2).)

(h) If a violation of Article 3 of this agreement (safety rules) results in damages, both vessels shall report the incident to their respective associations for investigation and settlement. (Article $6(3)$. 
(i) The agreement shall be valid for one year. (Article 11.)

(j) Both parties shall urge their respective Governments to enter into negotiations for a fisheries treaty with a view to settling speedily the Sino-Japanese fisheries question. (Article 9.)

Under an exchange of notes on the same date, ${ }^{85}$ the CFA informed the JCFA of the establishment of four zones: (a) the Military Alert Zone in the north (connecting the eastern base of the Liaotung Peninsula to the tip of the Shantung Peninsula) which Japanese fishing vessels may not enter without special permission; (b) the Military Prohibited Navigation Zone (around the mouth of the Ch'ien-t'ang River) to which Japanese vessels are barred; (c) the Military Activity Zone in the south (encompassing Taiwan and its environs) which Japanese vessels may enter only at their own risk; and (d) the MotorTrawler Forbidden Zone (connecting the Military Alert Zone to the Military Activity Zone) which both Chinese and Japanese motortrawlers are prohibited to enter.

The Japanese acquiesced in the first two zones on the understanding that their establishment would not result in discrimination against Japan. With respect to the third zone, the Japanese recognized the spirit of the advice and undertook to inform Japanese vessels accordingly. Concerning the fourth zone, although the Japanese recognized that the internal law of a country could not apply to the high seas so as to restrict the rights of other countries, they nevertheless accepted the spirit which motivated the Chinese Government to prohibit fishing by motor-trawlers within the zone, and promised voluntarily to forbid Japanese vessels to fish therein. ${ }^{86}$

The agreement was successively renewed until the Nagasaki Flag Incident of May 2, $1958^{87}$ caused a deterioration in Sino-Japanese relations. Four days after the incident, the CFA protested to JCFA against alleged violations of the Fisheries Agreement. ${ }^{88}$ Between May 6th and 13th, sixteen Japanese fishing vessels with 194 crew members were captured in the southwestern part of the Eastern Sea for allegedly intruding into a prohibited fishing area and the Military Activity Zone. Through the intercession of JCFA and the Japan-China Friendship Association, all but four vessels and two crewmen were subsequently

$85 I d$. at 276.

86 Letter from JCFA to CFA, April 15, 1955, in 2 JIH-PEN WEN-T'I WEN-CEIEN HUI-PIEN (Collection of Documents on the Japanese Question) 239 (1958).

87 In this incident a flag of the PRC on display at a fair in Nagasaki was insulted by Japanese who were later punished by imposition of a Y.500 fine. 2 JIH-PEN WEN-T'Y WEN-CEIEN HUI-PIEN, sicpra note 86 , at 214 . See also 3 id. at 43 .

88 Protest cable from CFA to JCFA, May 6, 1958, in 2 id. at 245 . See also JEN-MIN JIH-PAO, May 7, 1958, at 5. 
released by the Shanghai Security Bureau, but all attempts by JCFA to renew the agreement failed. On June 11, 1958, one day before the expiration of the agreement, JCFA expressed its regret to CFA concerning the impending termination of the agreement. It described the implementation of the twice-renewed agreement as "healthful and completely satisfactory," and as having contributed to the friendly and mutually beneficial relations between the two countries. Despite the expiration of the agreement, JCFA pledged to continue to request the Japanese Government to establish normal relations with the PRC and, on its own part, to strictly supervise the activities of Japanese fishing vessels in conformity with the letter and spirit of the fisheries agreement, expressing hope that a fisheries agreement would be concluded before long. ${ }^{80}$

Although the decision of JCFA to comply unilaterally with the letter and spirit of the expired fisheries agreement had much to do with arresting a further deterioration of Sino-Japanese fisheries relations, it could not have accomplished the task alone. China, as the coastal state, could have imposed drastic restrictions on Japanese fishermen. Such emergency measures as those relating to rescues or shelter in Chinese ports must perforce depend on Chinese cooperation and participation. With the lapse of the fisheries agreement and in the face of continued diplomatic non-recognition, what avenues were left for fisheries cooperation between the two countries?

Further ingenuity and improvisation was required. In 1959, while attending the 10th anniversary celebration of the founding of the PRC, the visiting Japanese delegation came to an understanding with Chinese officials on the basis of which an agreement providing for emergency rescue of and shelter for fishing vessels was signed between the Chinese People's Foreign Cultural Association and the JapanChina Friendship Association. The two associations worked towards further measures for preventing and settling disputes. They even went beyond the old agreement by organizing an exchange of visits between Chinese and Japanese fishermen. This emergency agreement was finally superseded by the 1963 Fisheries Agreement. ${ }^{00}$

The 1963 Fisheries Agreement was born of improved SinoJapanese relations and followed closely upon the signing of the LiaoTakasaki Trade Memorandum of November 9, 1962.91 It was similar to the 1955 agreement, except:

89 Information obtained from annual business reports issued in Japanese by JCFA.

80 See joint declaration by five Chinese and Japanese organizations on the signing of the Sino-Japanese civil fisheries agreement, Nov. 9, 1963, in 5 JIH-PEN WEN-T'I WEN-CHIEN HUI-PIEN, sipra note 86 , at 125 .

91 See text accompanying notes 97-121 infra. 
(a) The numbers of Chinese fishing vessels permitted to enter two of the six zones (Zones 3 and 6 ) were raised to the same levels as those for the Japanese, perhaps indicating expanded fishing activity on the part of China.

(b) Fishing vessels of one party could also enter the ports of the other under the emergency entry rule of Article 4(2) if they were escorting a rescued crew or vessel.

(c) The number of Chinese ports in which Japanese fishing vessels could seek shelter was reduced from three to two, with the maximum number of vessels specified as 50 for Wu-sung and 30 for Lien-yun. (Article 4(2).)

(d) A more detailed method of communication between fishing vessels and port authorities was provided in the 1963 agreement.

(e) Exchange of fisheries experts and technicians was added to the exchange program under Article 5.

(f) The duration of the agreement was increased from one to two years. (Article 11.) ${ }^{\mathbf{9 2}}$

Any attempt to evaluate Chinese compliance in regard to these fisheries agreements must take into account the fact that thousands of vessels are engaged in fishing off China's coast every year and hundreds are in the six specified zones alone. Violations and disputes invariably occur from time to time. The problem is multiplied by the small size of these vessels (most of which are below 100 tons) and by language barriers. The following observations may nevertheless be made, based on personal interviews with officials of JCFA and the Japanese Foreign Office as well as an exhaustive study of JCFA reports through the years.

A few incidents may be described to illustrate the type of problems involved and Chinese attitudes toward them:

After a collision between the Japanese fishing vessel Manzan Maru and the Chinese fishing vessel Shantung No. 14, on December 16, 1962, the former rescued all the Chinese crew and began to tow the Chinese vessel to port. In the course of the towing, the Chinese vessel sank. The Japanese captain admitted that, contrary to regulations which required two men on the watch, there was only one man on watch at the time of the collision. The Chinese admitted that at

9212 PRC TREATY SERIES 254. Under the new Agreement and related exchange of notes signed in Peking on December 17, 1965, the following changes have been made in the 1963 Agreement: (a) The areas covered by Zones 1 and 2 have been slightly changed; (b) A special conservation zone has been created in which each country is limited to sending 80 vessels during four months every year; and (c) Provision has been made to protect young fish and to regulate the size of dragnet meshes. 
the time of the original collision, although their vessel was stationary, it carried a light signalling that it was moving, thus misleading the Japanese vessel. The Chinese expressed appreciation for the action taken by the Japanese vessel after the collision and, indicating that the question of compensation was not as important as the maintenance of friendly relations with the Japanese, decided to share the responsibility and the damages. ${ }^{93}$

In another incident, a Japanese crewman on board No. 62 Fukuho Maru suffered an injury as a result of firing from a Chinese vessel. The expenses incurred for his hospitalization and treatment in Japan formed the subject of negotiations between the CFA and JCFA. The Chinese stated that they had imposed penalties upon the Chinese vessel and its captain for violating rules prohibiting firing at unarmed fishing vessels. However, they disclaimed external financial liability on the ground that the firing occurred when the Japanese vessel was attempting to flee from the scene. The CFA did send "condolences" to the Japanese crewman, which included a gift of an unspecified sum of money. ${ }^{94}$

It may be noted that incidents of collision and destruction or damage of fishing gear usually result in losses to the Chinese rather than to the Japanese, because Japanese vessels are usually made of steel, are of the ocean-going type of 85,89 or 99 tons and possess stronger and newer fishing equipment, whereas the Chinese fishing fleet consists of many small fishing junks capable of operating on coastal waters only. In many such incidents, the JCFA, upon establishing its responsibility after investigation, would impose fines upon the guilty or suspend the captains' or vessels' licenses to operate in the fishing zones for specified periods of time, and pay for the damage caused to the Chinese side.

Article 6(2) of both the 1955 and 1963 fisheries agreements calls for on-the-spot settlement of disputes wherever possible; many disputes have indeed been so resolved. According to an official JCFA report concerning the settlement of fifteen incidents involving Chinese and Japanese fishing vessels between November, 1958, and March, 1959a period when no fisheries agreement was in force-the Chinese were characterized by the Japanese as having expeditious ways of resolving disputes on the spot. Eight of the incidents involved compensation for damages caused to Chinese nets, ropes and buoys. The Chinese attitudes on these occasions were described by JCFA as "generally

93 JCFA, Records of the Second Conference on the New Japan-China Fisheries Agreements, November-December, 1965, Peking 147 (1966) (text in Japanese).

94 Id. at 121 . 
friendly." JCFA believed that, given a "sincere Japanese attitude towards negotiation," conflicts could be avoided. ${ }^{95}$

Considerable disagreement exists, however, over Chinese charges of espionage activities by Japanese fishing vessels. JCFA believed that such incidents were largely the result of misunderstanding. For example, two Japanese fishing vessels-Himeshima Maru and Mishima Maru-were confiscated in Shanghai on the ground that they were engaged in military espionage. According to a statement by one of the crewmen who returned to Japan, the captains of the two vessels incurred Chinese suspicion when they threw the log books into the water while the vessels were detained in the port of Shanghai. The $\log$ books were subsequently retrieved by the Chinese and the captain and the radio operator of the Himeshima Maru were sentenced to four and three years of forced labor respectively by a Shanghai court on October 31, 1958. Both were released after one year through the good offices of the Chinese Red Cross and the Japan-China Friendship Association.

The captains of the 5th and 8th Showa Maru aroused Chinese suspicion when, according to the report of one of the returned crewmen, they burned their fishery diaries and a radio operator burned his communication record. According to other crewmen, some Japanese vessels did intrude into the prohibited areas to take measurements of the depth of the sea bottom in violation of the fisheries agreements. A code book compiled by the Japanese Trawler Association for use by trawlers in order to avoid capture by Korean naval vessels for violations of the "Rhee Line," was mistaken by the Chinese for a military intelligence code. Certain fishing vessels appointed by the Japanese Meteorological Society to report back information on weather conditions in its own code and some companies using abbreviated codes in communicating with their vessels have also been viewed with suspicion by the Chinese. Finally, some fishermen carried with them binoculars or cameras, which the Chinese considered to be evidence of intelligence operations. In the end, JCFA instructed all relevant bodies to desist from any activity which might even remotely lend itself to suspicion by the Chinese authorities. ${ }^{96}$

As a final observation, it is noteworthy that in its 1966 petition to the Japanese Foreign Office for normalizing Sino-Japanese fisheries relations, JCFA pointed out that of the 109 Japanese fishing vessels still detained in China, 104 were captured between 1950 and 1954, and five were confiscated in 1958-all periods when no fisheries agreement was in force. 


\section{E. Trade Agreements}

\section{Japan}

Despite Japan's continued recognition of the Nationalist Government on Taiwan and close military, political and economic ties with the United States, its trade volume with mainland China reached an all-time high of $\$ 621$ million in 1966 (a 32 per cent increase over the preceding year) and is now second in size only to Japanese trade with the United States. By contrast, its trade with Taiwan remained about $\$ 300$ million for $1966 .{ }^{97}$

Moreover, notwithstanding the "Great Proletarian Cultural Revolution," which Japanese sources expected to settle down around the summer of $1967,{ }^{98}$ the volume of both-way trade for 1967 was still expected to increase by 10 per cent over that of 1966, reaching around $\$ 700$ million. $^{99}$ Indeed, it has been predicted that total trade will reach $\$ 1,000$ million within a few years, ${ }^{100}$ despite the many political and economic vagaries to which Sino-Japanese trade is subject. Not the least of these is the tendency of the Coordinating Committee for Export Control to ease control on exports to Russia and Eastern Europe, while tightening controls against mainland China. ${ }^{101}$

The continued growth of Sino-Japanese trade may be attributed to the complementary nature of the trade and the geographical propinquity of the two countries. China's exports to Japan consist largely of agricultural produce and raw materials, while Japan's exports to China consist mainly of chemical fertilizers, steel and machinery. As early as 1955, Peking's Vice Minister for Foreign Trade, Lei Jen-min, underscored the geographic element when he cited the fact that it took only two days to reach Nagasaki from Shanghai and four days to cover the distance between Tientsin and Kobe. Transportation for

97 This "Great Leap Forward" in Japan-mainland China trade may be seen from the following table:

(Note: $a=$ approximate)

Recent Sino-Japanese Trade Volumes

$\begin{array}{cccc}\text { Year } & \text { Exports } & \text { Imports } & \text { Total } \\ 1960 & 2,726 & 20,729 & 23,455 \\ 1961 & 16,639 & 30,895 & 47,534 \\ 1962 & 38,457 & 46,020 & 84,477 \\ 1963 & 62,417 & 74,599 & 137,016 \\ 1964 & 152,739 & 157,750 & 310,489 \\ 1965 & 245,036 & 224,705 & 469,741 \\ 1966 & 315,000 \mathrm{a} & 306,000 \mathrm{a} & 621,000 \mathrm{a}\end{array}$

Unpublished statistics compiled by the Japanese Ministry of Finance, Dec. 1966.

88 Japan Times, Jan. 27, 1967, at 8, col. 1.

99 Japan Times, Jan. 29, 1967, at 10, col. 1 .

100 Japan Times Weekly, Nov. 12, 1966, at 7, col. 1.

101 Japan Times, Dec. 30, 1966, at 8, col. 1. 
one ton of coal from the United States to Japan, he said, cost $\$ 17$, whereas that from China to Japan cost only about $\$ 3 .{ }^{102}$ Although these figures may have changed since then, the basic factor remains the same. Along with racial, cultural and historical affinities, these factors could not help but incline the two countries to a close economic relationship.

There are interesting parallels between the Sino-Japanese fisheries agreements and the trade agreements. Both have been concluded on the Associational instead of the Governmental level and both are regarded as unofficial by Japan, but considered to be semi-official by the PRC, which includes the texts in its Treaty Series. Moreover, both were affected by the Nagasaki Flag Incident in 1958 and recovered almost simultaneously in 1963.

Almost all Sino-Japanese trade transactions currently are channeled through the Liao-Takasaki and friendly-firm arrangements. The background and character of each of these agreements will be briefly described.

From 1952 to 1958, Sino-Japanese trade was conducted through four different trade agreements subject to renewal. ${ }^{103}$ These trade agreements aimed at an annual export-import balance in specified categories of commodities, with the maximum volumes each way varying between $£ 30$ million and $£ 35$ million per year. In the event of a dispute over the terms of the agreements, recourse would be had to arbitration. The first two agreements named China as the place for arbitration, with an arbitration commission to be composed of members from both countries; the last two specified the defendant state as the place for arbitration and also provided for a mutually acceptable third-party arbitrator to serve in the commission. Because of trade embargoes during the Korean War, the maximum trade volumes were far from being reached. Thus, despite the June, 1952 trade agreement, which set the maximum both-way trade volume at $f 60$ million, actual volume reached only 5.5 per cent of that figure, or a quarter of the 1950 trade volume. Only 38.8 per cent of the trade target set under the October, 1953 agreement was reached, with China's exports to Japan doubling Japan's exports to China. Under the third agreement of May, 1955, China's exports to Japan reached 78 per cent of the target as compared to Japan's exports which reached only 30 per cent. ${ }^{104}$

Under Article 10 of the third trade agreement, each side could establish a resident trade mission in the capital of the other side. The

1022 JXH-PEN WEN-T'I WEN-CHIEN HUI-PIEN, supra note 86, at 171-72.

103 Texts of these agreements are in 2 PRC TREATY SERIES 367, 368; 4 PRC Treaty SerIes 258; 7 PRC Treaty Series 197.

1042 JIH-PEN WEN-T'I WEN-CHIEN HUI-PIEN, supra note 86, at 171-72. 
mission and its personnel would be accorded "diplomatic" immunities. Under Article 2 of the same agreement, both sides pledged to work towards an early fulfillment of these provisions, as well as to urge their Governments to negotiate and conclude a commercial treaty at the earliest possible date. These provisions, however, apparently sowed the seeds of disharmony between the two countries. The Japanese Government, although welcoming increased trade with the PRC, was nevertheless politically committed to recognition of the Nationalist Government and to a pro-United States policy. It insisted that any Chinese trade personnel residing in Japan for a period longer than two months must fulfill a fingerprinting requirement which was viewed as humiliating by Peking. ${ }^{105}$ This and other obstacles prevented the exchange of trade missions, as well as the holding of Chinese trade fairs in Nagoya and Fukuoka in 1957.

Following a visit to Peking by a Japanese trade delegation in the fall of 1957, the fourth trade agreement was signed on March 5, 1958. This agreement omitted the controversial "diplomatic" provision. Instead, under a separate memorandum regarded as an integral part of the agreement, trade missions and their personnel were to be accorded freedom of travel and communication, including the right to use codes, the right to display national flags on their buildings and exemption from fingerprinting. Procedures for the settlement of disputes by joint agreement also were included. The Japanese Government, however, adamantly refused to agree to the flag privilege in view of its diplomatic recognition of the Nationalist Government. In the midst of this controversy, there occurred the Nagasaki Flag Incident, ${ }^{106}$ which prematurely terminated the 1958 agreement. Also terminated were negotiations by two Chinese mining corporations for the purchase of 158,000 tons of steel in Japan. ${ }^{107}$ The two corporations had entered into a five-year agreement on February 26, 1958 with Japanese metal representatives for the trading of Chinese iron and coal products for Japanese steel products. The export volume from each side for the five-year period had been set at $£ 100$ million. ${ }^{10 s}$

During the trade interruption, Peking laid down a number of preconditions for resumption of trade with Japan, including three political preconditions: abandonment of any anti-Chinese policy, nonparticipation in a "two-China" scheme, and nonfrustration of normal relations between China and Japan; ${ }^{109}$ three concerning trade channels: govern-

105 See Editorial of Jen-min Jih-pao, Aug. 7, 1957, at 7.

108 See note 87 supra.

1072 JIH-PEN WEN-T'I WEN-CHIEN HUI-PIEN, supra note 86, at 213.

108 Id. at $185-87$.

1003 id. at 57. 
mental agreements, nongovernmental contracts and individual contacts; and adherence to the principle of nonseparation of politics from economics. ${ }^{110}$

On September 19, 1962, at a farewell party given in Peking by Mr. Matsumura, a Diet member and adviser of the Liberal Democratic Party, Premier Chou reiterated the above preconditions as guiding principles for Sino-Japanese trade. However, he also indicated that these preconditions constituted only long-term objectives and that trade could resume on a gradual basis beginning from the people's level. ${ }^{111}$ The Matsumura visit was soon followed by that of former Minister of Trade Takasaki, resulting in the Liao-Takasaki Memorandum of November 9, 1962.112 Under this memorandum, a five-year trade plan (1963-1967) was mapped with an average volume of $£ 36$ million per year. (Article 1.) China would export coal, iron ore, soy beans, maize, mixed beans, salt and tin, while Japan would export steel (including special steel), chemical fertilizers, agricultural medicines, agricultural machines and implements and factories. (Article 2.) Each transaction under the memorandum was to be consummated by separate contracts between Japanese concerns and one of the PRC's foreign trade corporations. (Article 3.) Both sides agreed to promote technical exchange and cooperation. (Article 6.)

Unlike the four trade agreements concluded between 1952 and 1958, the present memorandum did not provide for methods of arbitration, which must form the subject of a separate agreement. (Article 7.)

The bottleneck which prevents a much greater trade volume lies in Article 5, which requires the conclusion of separate agreements for long-term credits or installment payments, both of which are under rigid Japanese government control. The effect of Article 5 thus has been to deny the PRC such credits or installment payments.

Under the five-year memorandum, an annual agreement must be concluded separately to fix the volume of trade as well as the price, quantity and quality of each commodity to be transacted for in each particular year. The terms of these annual agreements are not made public, although their general contents may be ascertained through monthly publications of trade statistics by the Japanese Ministry of Finance.

A close balance between exports and imports in specified categories of goods is sought. For example, the sales volume of Japanese steel or iron to China is geared to the volume of Japanese purchases of pig

$110 \mathrm{Id}$. at 135 .

$1114 \mathrm{id}$. at 17-19.

112 Id. at 90 . 
iron from China, and Chinese purchases of Japanese fertilizers are tied to Japanese purchases of Chinese rice. After the target has been set, experts from both sides are to decide on the quantity and price of each item. Firms are nominated by both sides, largely on the basis of their past reputation. Increasingly, however, the Chinese have taken the initiative in these nominations. Negotiation with Japanese firms on specific items is conducted by one of the state-owned export-import corporations headquartered in Peking, assisted by the Liao office. These corporations are in turn under the over-all coordination and supervision of the China Council for the Promotion of International Trade. Payments are based on the pound sterling through London.

Under a separate memorandum of April 19, 1964, agreement was reached on the establishment of a Takasaki Liaison Office in Peking and a Liao Chen-chih Liaison Office in Tokyo. Each side could temporarily appoint three representatives and two staff members to its office for one year's duration, with each assuming responsibility for the safety of the other side's personnel, as well as for handling their entry procedures. The personnel of both sides were to arrive in their offices by the middle of June, $1964 . .^{113}$ It should be noted that conspicuously omitted from this memorandum was the right of the offices to display national flags - a source of much controversy heretofore.

In addition to trading under the L-T agreements, a considerable number of transactions have been consummated through what has become known as "friendly firms." Some friendly firms also take part in L-T trade, and some of the items within the L-T targets may also be the subject of transactions by friendly firms, which engage in more items of trade than L-T. These firms, after being found acceptable to Peking, usually send representatives to visit the semiannual trade fairs in Canton. There, along with traders and manufacturers from other nations, they close many deals with Peking. ${ }^{114}$ The lapse of trade agreements between 1958 and 1963 due to the Nagasaki Flag Incident also resulted in the absence of Japanese participation in the Canton fairs during that period.

The proportion of trade concluded by $\mathrm{L}-\mathrm{T}$ and friendly firms since 1963 may be seen from the following table: ${ }^{115}$

11313 PRC TREATY SERIES 386.

114 The Canton fair was first begun in the spring of 1957, the twenty-first fair being held on April 15, 1967, for a one-month period, notwithstanding the Cultural Revolution. At least 250 Japanese business firms and more than 800 of their representatives planned to participate in this fair, as compared to 230 firms and 750 representatives participating in the autumn fair held in October, 1966. Japan Times, Jan. 29, 1967, at 10, col. 3. This increase amidst the Cultural Revolution is most impressive in view of the fact that spring fairs in Canton are usually smaller in scale than the autumn ones.

115 Statistics supplied by the Japanese Ministry of Foreign Affairs in Tokyo in December, 1966. 


$\begin{array}{ccc}\text { Year } & L-T \text { Trade } & \text { Friendly Firms } \\ 1963 & 47 \% & 53 \% \\ 1964 & 37 \% & 63 \% \\ 1965 & 36 \% & 64 \% \\ 1966 & 33 \% & 67 \%\end{array}$

The table reveals that the share of L-T trade in the total volume decreased with the passage of time, while that of friendly firms increased. Thus, for the fifth year of the L-T agreement, the absolute sum of L-T trade is expected to decrease from $\$ 204$ million in 1966 to $\$ 184$ million in 1967 (roughly $\$ 84$ million of imports from China to Japan and $\$ 100$ million of exports from Japan to China), chiefly due to a cut in Japan's importation of Chinese rice from 300,000 tons to 200,000 tons. The friendly firms' share, on the other hand, is expected to go up not only in absolute terms, but also proportionally, in view of expected increases in the total trade volume to about $\$ 700$ million for 1967 from $\$ 621$ million for 1966. Such a trend may be explained in part by the stronger bargaining position which Pelking holds vis-à-vis individual friendly firms than under the L-T trade. Furthermore, by awarding contracts selectively and strategically, China can reap a political as well as an economic harvest.

In addition, one may note with interest a change in the balance of trade in recent years. Unlike the 1952-1958 period, in which China's exports to Japan far exceeded Japan's exports to China as a result of the trade embargo policy, trade statistics in the last few years reveal a reverse trend; in 1965, exports from Japan to China amounted to $\$ 245$ million as compared to $\$ 224$ million worth of Japanese imports from China. Between January and June of 1966, exports from Japan to China amounted to $\$ 164$ million, while imports from China to Japan were $\$ 156$ million. ${ }^{116}$

On the question of Chinese compliance with the various trade agreements and contracts with friendly firms, it is unanimously conceded that the Chinese have always met their financial obligations promptly. Indeed, China has an excellent international credit rating, based on its payment of debts to the Soviet Union and its meeting of obligations for wheat purchased from Canada and Australia. ${ }^{117}$ Disputes "very rarely" occur, whether over the quality of the commodities or other terms of the agreements. Should disagreement arise, it is invariably settled by negotiation and conciliation rather than arbitra1966.

116 Statistics supplied by an official of a "friendly firm" in Tokyo, in December,

117 Japan Times Weekly, Nov. 12, 1966, at 7, col. 2. 
tion, ${ }^{118}$ and the Chinese position has, on the whole, been represented to the author as one of reasonableness and understanding.

The abrupt cancellation of the 1958 trade agreement may have been justified. It can be argued that the Japanese government had frustrated the carrying out of substantive provisions of this agreement by putting obstacles in the way of the establishment of a Chinese trade mission in Japan, and by denying the mission's right to display the Chinese flag. These rights had been assured in the agreement, a Japanese negotiator having interrupted a session in order to return home for consultation with the Japanese government before agreeing to them. ${ }^{119}$

During the current turmoil wrought by the Great Proletarian Cultural Revolution, congestion in Shanghai and other Chinese ports has resulted in delay in the loading and unloading of ships. In one instance, a Japanese ship had to remain in port for twenty days before the loading and unloading work was completed, as compared with the two or three days required in normal times. ${ }^{120}$ Whether or not these delays resulting from Red Guard activities may be considered as force majeure, like labor strikes, is not clear at this writing. It may be noted that such delays occur more often with Japanese vessels than those of other nationalities, because contracts involving the former do not usually contain a demurrage clause. As a result, Japanese vessels are often serviced last during periods of port congestion or labor shortage.

When Japanese workers and technicians are sent to China in fulfillment of an agreement or contract, they are generally quartered in places segregated from the Chinese people, in part for reasons of convenience. They must obtain prior permission to travel, but such permission has been given quite freely. No incident or dispute between them and the Chinese people or authorities has been reported.

Occasionally, the Chinese may time the announcement of trade transactions with Japan in such a way as to gain maximum propaganda effect. For example, transactions with friendly firms involving $\$ 50$ million worth of goods had been agreed upon in Peking prior to the 1966 autumn fair in Canton. However, the actual signing was postponed until the holding of the Canton fair, probably to enable Peking to claim that a total of $\$ 130$ million worth of transactions had been consummated in Canton, instead of only $\$ 80$ million. This had the effect of accentuating the importance of the fair, although the $\$ 130$ million figure was technically correct. 
One of course may question the appropriateness of international trading on a "friendly firm" basis. There is perhaps only a difference of degree between this and various other state practices. Thus, the state-owned Central Trust of China, Nationalist China's official purchasing agency, recently announced that the Nationalist Government had canceled a contract for the purchase of 333 tractors from two Japanese firms. A Tokyo report said a visit to mainland China by the board chairman of one of the firms in December, 1966, might have jeopardized the deal. ${ }^{121}$ The Trust's spokesman explained: "It is our persistent policy to have no dealings with Japanese firms which do business with Chinese Communists."

\section{Canada}

During the late nineteen fifties natural calamities, accentuated by economic dislocations resulting from the Great Leap Forward and the communes, made necessary China's massive importation of food. Russia, which was already withdrawing its technical and economic assistance from China-the first visible impact of an ever-widening ideological cleavage-was in no mood to alleviate China's food shortages. China was forced to turn to Western countries and found receptive sellers in Canada, Australia, Argentina and France. For the purpose of this study, it suffices to concentrate on her dealings with Canada. Despite the vast geographical, racial, historical, cultural, religious, political and economic differences between Japan and Canada, their relations with China are marked by great similarities: both engaged in substantial trade with the PRC despite official nonrecognition; both experienced meticulous Chinese compliance with trade agreements or contracts.

Unlike the Sino-Japanese essentially balanced multi-commodity trade, however, Sino-Canadian trade has been characterized by a oneway wheat-barley sale from Canada to China. Also, while China includes its trade agreements with various nonofficial Japanese bodies in its Treaty Series (persuasive evidence that these were given a semiofficial status), it has refrained from including its agreements with Canada therein, probably because these agreements have been concluded on the Chinese Corporational level instead of on the Associational level as in the case of Japan. Although the precise implications of this difference are not known, the Canadian agreements are included in the present study for comparative purposes.

In January, 1961, a large sale was negotiated between the PRC and Canada, consisting of 750,000 long tons of wheat and 260,000 
long tons of barley. Later, a second sales contract was signed for 60,000 long tons of wheat. Both sales were for cash, and prompt shipment was made at China's request. ${ }^{122}$ In April, 1961, a long-term agreement, covering the period from June 1, 1961, to December 31, 1963, was concluded following negotiations in Hong Kong and Peking. In this agreement, Peking declared its intent to purchase a maximum of five million long tons of wheat and one million long tons of barley from Canada, with the actual quantities and prices to be decided by subsequent negotiations which since have been conducted on the average of about twice a year.

Pursuant to this umbrella agreement, a sales contract was signed involving 750,000 long tons of wheat and 360,000 long tons of barley. A deferred payment was arranged to allow Peking to pay 25 per cent in cash at the time of loading and the balance nine months thereafter. Payments were in pounds sterling through London. Subsequent to this, another sales contract was signed involving 160,000 long tons of wheat for shipment from St. Lawrence ports, with a similar deferred payments arrangement. The above contracts alone involved a total of 64.2 million bushels of wheat and 28.9 million bushels of barley. ${ }^{123}$

Since these initial contracts, the "wheat deal" between Canada and China has become a regular feature of international trade. Out of some 174 million bushels of wheat imported by China for the crop year 1963-1964, ${ }^{124}$ Canada supplied $41,286,001$ bushels. ${ }^{125}$ Canada's sales in 1964-1965 increased in both absolute sum and percentage: it supplied 62,370,202 bushels out of a total of 222 million bushels imported by China, which made China the second largest wheat customer of Canada after the United Kingdom. ${ }^{126}$ In the 1965-1966 crop year, about 80 million bushels were sold to China; for 1966-1967, an estimated 93 million bushels are scheduled to be sold. ${ }^{127}$ The average price is about two Canadian dollars per bushel.

Just as diplomatic nonrecognition between Japan and the PRC necessitated the conclusion of the fisheries and trade agreements on the Associational instead of the Governmental level, similar circumstances in Sino-Canadian relations resulted in wheat agreements being concluded between the Canadian Wheat Board (CWB) and the China Resources Corporation (CRC). The former is a Crown Agency,

122 See Annual Report of the Canadian Wheat Board-Crop Year 19601961, at 9.

123 Id. 1965).

124 Internationai Wheat Council, Record of Operations, 1964-65 (Nov. 3,

${ }^{125}$ Annual Report of Canadian Wheat Board, 1964-1965, at 11 (1966).

126 Id. at 10-11.

127 Japan Times, Dec. 11, 1966, at 10, col. 3. 
established in 1935 by the Canadian Wheat Board Act ${ }^{123}$ as an autonomous body reporting to the Minister of Trade and Commerce. As the sole marketing agency for wheat, oats and barley grown in western Canada (which provides some 95 per cent of exported wheat), it deals with some twenty to thirty large trading firms. CRC is a stateowned export-import corporation with its headquarters in Peking and a large branch office in Hong Kong. Negotiations are conducted directly between CWB and CRC in Hong Kong or Winnipeg, Manitoba. In the former case, the facilities of the Canadian Trade Commissioner in Hong Kong are used. The length of negotiations is between two and six weeks. Occasionally, chief negotiators from the PRC are officials of the China National Cereals, Oils and Foodstuffs Import and Export Corporation, although final signatures are affixed by officials of CRC.

The 75 per cent deferred payment arrangement is by a "Usance Draft" or 547-day (18-month) credit. This doubles the terms of the 1961 arrangement under which a 273-day credit was allowed. Although such drafts are usually guaranteed by the Export Credits Insurance Corporation, thereby enabling Canadian concerns to obtain commercial credits from banks, in the case of the China trade the Corporation issues credits itself on the same commercial rate, probably to avoid the possibility of any blacklisting. Transportation is usually by Peking-chartered vessels arranged through Chinese representatives in Vancouver.

In all these transactions, the Canadians have found Chinese payments to be punctual and, indeed, even ahead of deadlines. There has been no complaint whatsoever by the Canadians against the Chinese in meeting their commitments under the various agreements. Occasionally, grain loaded on the east coast of Canada is diverted to Albania, and that loaded on the west coast to North Korea. However, these diversions are not forbidden by the agreements.

A minor complaint raised by the Chinese but satisfactorily resolved may be cited to illustrate the working relationship between CWB and CRC. It involved the alleged failure of Canada to meet the Chinese "Phyto" sanitary requirement (freedom from insects). After a thorough investigation conducted by the Canadian Board of Grain Commissioners, the Chinese were informed that sanitary conditions in elevators were up to standards and that there was no evidence to sustain charges of damage. The Chinese accepted the finding of the Board and considered the matter closed. 


\section{Cuba}

The inclusion of Cuba (a Latin American as well as a socialist country) in this study is influenced not only by the need for balanced coverage, but also by Premier Fidel Castro's denunciation of Peking in 1966 for allegedly breaching an agreement by reducing its rice-sugar trade with Cuba.

Cuba was the first and only Latin American country to recognize the PRC (on September 2, 1960). In the upheavals that followed Cuba's political and ideological realignment, it had to readjust its trade pattern, changing from near-domination by United States trade to close economic ties with fellow socialist countries. The transition was difficult and the task arduous. Distance alone presented a staggering problem; instead of crossing a mere 90-mile strait, trade now had to be conducted from one end of the world to the other. The problem was not made any easier by the fact that Cuba is essentially a singlecrop nation and, hence, must import a great variety and quantity of goods. Further, its once great tourism industry had dwindled to a trickle, and new tourists lacked the resources of the former American ones.

It was in this setting that Cuba looked to Chinese trade and assistance. Despite the distance between the two countries, the Cuban need for rice and the Chinese need for sugar appeared to lay a sound foundation for long-term trade. Indeed, a 1964 Cuban proposal to China suggested that, since the price of sugar in China was five times that of rice, and the price of rice in Cuba two to three times that of sugar, a mutually beneficial exchange of two tons of Cuban sugar for one ton of Chinese rice should be adopted..$^{129}$

The first trade and payments agreement between Cuba and the PRC was signed on July 23, 1960-even before Cuba had extended diplomatic recognition to China. Under this agreement, China agreed to import 500,000 tons of sugar every year over a five-year period..$^{130}$ Subsequently, a commodity exchange agreement was concluded on February 22, 1963, on the Ministry of Foreign Trade level. This agreement outlined detailed regulations covering the transport of goods by sea and air, quality inspection, weight and measurement, payment methods, release of obligations, penalties and arbitration. ${ }^{131}$ On December 31, 1964, five separate agreements were concluded on the

129 Speech by Premier Fidel Castro on the 7th anniversary of the Cuban Revolution, Jan. 2, 1966, in Cuban News No. 48 at 1, 9 (Cuban Embassy, Tokyo, Feb. 15, 1966) (in Japanese).

13010 PRC TrEaty SerIes 238.

13112 PRC Treaty Series 125-39. 
subjects of trade, payments, trade for 1965 , commodity exchange and sugar sales. ${ }^{132}$

However, the Sino-Soviet ideological disputes had reverberations in Cuba: vehement Chinese attacks on Soviet revisionism and foreign policies were often published in such journals as Peking Review, whose Spanish edition was regularly imported by the Chinese Embassy in Havana for distribution to Cubans. To the Chinese, the importation and distribution of these materials fell properly under the government information program sanctioned by the cultural cooperation agreement of July 23, 1960. ${ }^{133}$ However, to the Cubans, who had received much Soviet aid and who now wished to steer clear of the Sino-Soviet dispute, these activities constituted illegitimate propaganda designed to influence Cuban public opinion. Accordingly, the Cuban Government requested the Chinese Embassy to cease such activities in the future, a request that did not please the Chinese.

In the midst of this dispute, in mid-November of 1965, a Cuban delegation left for Peking to negotiate a trade agreement for 1966, carrying with it a proposal for exports of 110 million pesos to China and imports of 140 million pesos from China. The proposal envisaged an increase of sugar and rice quotas over the preceding year. However, contrary to the Cuban expectation that the 1966 quotas would at least remain on the same level as those for 1965 , the Chinese stated that they could not agree to the importation of another 800,000 pounds of Cuban sugar since China had harvested a big sugar crop in 1965 and had completed repayment, in kind, of sugar loaned by the Soviet Union in 1961. Consequently, there would be less need for Cuban sugar, as evidenced by the abolition of sugar rationing in China. With respect to rice, China also said she would have to reduce her exports to Cuba. The export of 250,000 tons of rice to Cuba in 1965 was made in response to Castro's special appeal to the Chinese Ambassador, and could not be taken as a normal volume. Despite good rice crops in 1965, China could not send to Cuba more than 135,000 tons of rice, the same amount she had sent in 1964, in view of the necessity of stockpiling rice against possible American attacks, of sending rice to help the Vietnamese and of exporting rice in order to obtain hard currencies with which to pay for grains imported from capitalist countries.

In a speech delivered on January 2, 1966, Premier Castro denounced China's decision to halve its rice export to Cuba at a time when Cuba was unable to obtain rice from other countries because

132 See JEN-MIN Shou-TS'E (People's Handbook) 227 (1965).

13310 PRC TREATY SeRtes 388. 
of "American imperialism." He said that while the Chinese thought that the 1965 arrangement was for only one year, "frankly speaking, I thought the agreement was for a longer period." 134

While one might dispute China's professed reasons for reducing the rice-sugar trade with Cuba, it would be difficult to find any evidence of Chinese violation of an agreement with Cuba in light of the fact that the agreement in question was the subject of negotiations which had yet to be concluded. What was at issue appeared to be not the breach of an agreement, but the failure to reach a mutually satisfactory one.

\section{The Scandinavian Countries}

Finland was the first non-Communist country to conclude a trade agreement with the PRC on a governmental level. On September 21, 1952, a tripartite trade agreement was signed under which 34 million rubles in trade between the Soviet Union, Finland and China was planned for the remainder of $1952 .^{135}$ This was followed by the general trade agreement of June 5, 1953. ${ }^{136}$ Since then, annual agreements have been concluded which, except for upward changes in the annual quotas, are almost identically worded. To each of these agreements is appended a list of commodities which each country may export to the other. Prices are based on those prevailing in the world market. A separate payments agreement was also concluded on June 5, 1953, ${ }^{137}$ which, with subsequent amendments, governs the method of payments with respect to contracts concluded pursuant to these trade agreements. In addition to the trade and payments agreements, an exchange of notes on March 31, 1956 makes applicable the most-favored-nation doctrine ${ }^{138}$ in matters concerning customs exemptions and navigation..$^{130}$

Interviews in Helsinki with Finnish officials involved in the negotiation of many of these agreements indicate that negotiation with the PRC is always difficult, involving hard bargaining and frequent delays resulting from Chinese referrals to Peking for instructions on many matters which would normally lie within the discretionary power of a Western negotiator. However, once a result is reached, the Chinese can be counted upon to abide by their agreement.

134 Cuban News, supra note 129 , at 8-10.

1352 PRC TREATY SERTES 174.

138 Id. at 35 .

137 Id. at 37 .

$138 \mathrm{~A}$ most-favored-nation clause is generally included in major PRC trade agreements. Its purpose is to protect Chinese exports against discrimination in the world market and to defeat any embargo against the PRC. See WANG YAO-T'IEN, KUO-CEI MOU-I T'IAO-YÜEH HO HsEH-TING (International Trade Treaties and Agreements) 116 (1958).

1395 PRC TREATy SERIEs 61. 
Sweden's commercial treaty relations with the PRC are less extensive than those of Finland. Two agreements were concluded in 1957: a trade agreement on November 8 th $^{140}$ and an exchange of notes on copyrights dated April 6th and 8th. ${ }^{141}$ To these may be added an exchange of notes constituting an agreement on the establishment of consular relations, dated June 24, 1954, ${ }^{142}$ giving Sweden the right to establish a consulate in Shanghai, and the PRC the right to establish a consulate in Sweden "at a place to be agreed upon." Because of the lack of actual need, no consulate exists at present in either country.

Officials in Stockholm had shared Helsinki's views concerning Chinese compliance with treaty obligations. However, whether they will continue to hold this view is problematical in the light of a recent trade fair incident about which details are still lacking. After three years of negotiation with Peking authorities, a large Swedish industrial exhibition had been scheduled to take place in Peking April 3-13, 1967. A total of 136 Swedish firms, including SKF, makers of ball bearings, Volvo, Saab and Scnia-Vabis, were involved and had invested some $\$ 1,200,000$ in the project. About 200 Swedish businessmen planned to travel to Pelking for the opening of the exhibition, which was intended to boost substantially Swedish exports to China (amounting to $\$ 14,000,000$ in the previous year). The Swedes were encouraged by the fact that Atlas Copco, manufacturers of drills, had signed a contract with Peking in June, 1966, on behalf of a Swedish syndicate for the delivery of $\$ 7,000,000$ of mining equipment. A freighter carrying 450 tons of Swedish machines sailed with great ceremony from Gothenburg on December 5, 1966.

In late December, Swedish Ambassador to Peking, Lennart Petri, received notice that the exhibition would be canceled because the premises had been taken over by the Red Guards for storage purposes. ${ }^{143}$ A month later, however, the Federation of Swedish Industries announced that it would go ahead with the exhibition as planned. ${ }^{144}$ On February 6, 1967, a Swedish Foreign Office spokesman confirmed a newspaper report of the same date that the scheduled exhibition would not be held..$^{145}$

Although Chinese authorities had offered the Swedes another site in place of that taken over by the Red Guards, Swedish businessmen wished to send a delegate to Peking to inspect the new site before the

1406 PRC TREATY SERIES 181.

$141 \mathrm{Id}$. at 180.

142228 U.N.T.S. 154, at 154-56.

143 Japan Times, Dec. 28, 1966, at 9, col. 1 .

144 Japan Times, Jan. 26, 1967, at 12, col. 7.

145 Mainichi Daily News, Feb. 8, 1967, at 4, col. 1. 
exhibition was held. His application for a visa was reportedly not acted upon in time for the exhibition. Meanwhile, the freighter carrying the Swedish machines had arrived in Shanghai. Rather than take a chance on unloading and sending the machines to Peking only to find the fair site undesirable, the Swedes reluctantly decided to cancel the whole venture. They received refunds for the rents for the exhibition hall and decided to sell the exhibition goods in Shanghai and other ports and to bring back to Sweden only what could not be sold. ${ }^{146}$ Details are lacking as to the existence of any financial liability on the part of the Chinese authorities for losses incurred as a result of this incident.

It is interesting to note that, despite the Swedish misadventure, Danish industrialists went ahead with plans for an exhibition in Peking March 1-15, 1967. According to Mr. John Ljunggreen, an organizer for the Danish Committee for Foreign Exhibitions, the Chinese posed no problems for the Danes, and about seventy Danes were reported to have visited Peking. ${ }^{147}$ Apparently, the Danish exhibition was planned to be much smaller than the Swedish one and required only about a quarter of the space needed by the Swedes, which explains perhaps why it did not have to compete for room with the Red Guards.

A noteworthy event in Sino-Norwegian trade relations pertained to the settlement of a contract dispute by the Chinese Maritime Arbitration Commission. The Norwegian vessel M/S "Varild" went aground in Tungsha near Shanghai on April 4, 1961. It was salvaged by the Shanghai Salvage Bureau under a contract containing the standard form of the Maritime Arbitration Commission of the China Council for the Promotion of International Trade. A dispute arose over the amount of remuneration for the salvager who filed an application for arbitration with the Commission. Pursuant to Article 19 of the Rules of Procedure, the Arbitration Tribunal, with the consent of the disputants, proceeded with conciliation. In the end, concessions were made by both sides and the dispute was amicably resolved. ${ }^{\mathbf{1 4 8}}$

146 Svenska Dagbladet (Stockholm), Feb. 6, 1967, at 3.

147 Mainichi Daily News, Feb. 8, 1967, at 4, col. 1.

148 The M/S "Varild" Case. Maritime Arbitration Commission, China Council for the Promotion of International Trade, Peking. Conciliatory Conclusion: (63) Tiao Tzú No. 011. See also Decision of the State Council of the PRC concerning the Establishment of a Maritime Arbitration Commission within the China Council for the Promotion of International Trade, adopted on November 12, 1958, at the 82d Sesssion of the State Council; Provisional Rules of Procedure of the Maritime Arbitration Commission of the China Council for the Promotion of International Trade, adopted on January 8,1959 , at the 7 th Session of the China Council for the Promotion of International Trade.

For the establishment of the Foreign Trade Arbitration Commission and its activities, see Hsiao Fang-chou, Ten Years of the China Contncil for the Promotion of Intermational Trade, Foreign Trade of the People's Republic of China, No. 2 (Ser. No. 18) at 2, 3 (June 1962). 


\section{F. Economic Assistance}

The entry of the PRC into the field of foreign aid barely five years after its establishment reversed the century-old pattern in which China had always been on the receiving end of foreign largesse. Although a loan to Albania was granted under an agreement of December 3, $1954,{ }^{149}$ full-scale assistance programs did not begin until 1956, when the PRC concluded aid agreements with Cambodia, ${ }^{150}$ Mongolia, ${ }^{151}$ Nepal ${ }^{152}$ and Indonesia. ${ }^{153}$ Since then, loans or other types of assistance have been rendered to Ceylon, Yemen, Guinea, Burma, Ghana, Mali, Cuba, North Korea, North Viet Nam, Pakistan, Afghanistan, Syria, the United Arab Republic, Algeria, the Congo (Brazzaville) and Tanzania.

While occasional variations exist in the loan or aid agreements, the following distinctive features may be noted:

(1) Many Chinese agreements begin with the explicit statement that there are no strings attached to the aid and that there will be no interference in the internal affairs of recipient countries. ${ }^{154}$

(2) Loans are usually interest-free, repayable by installments over a ten-year period after a specified number of years. ${ }^{155}$ Some agreements additionally specify that repayments may be made in the form of mutually acceptable commodities of the debtor country or third countries. ${ }^{156}$

(3) Travel expenses and salaries of experts and technical personnel are usually to be paid by China, while their local living expenses are to be deductible from the aid funds. However, the standard of

1493 PRC Treaty Series 55.

1505 PRC TREATY SERTES 109.

151 Id. at 144.

$152 I d$. at 32 .

153 Id. at 57 .

154 E.g., Agreement on Economic Assistance Between China and Nepal, Oct. 7, 1956, 5 PRC TREATY SERIES 32; Highway Construction Agreement Between China and Nepal, Oct. 15, 1961, 10 PRC TREATY SERIES 423; Agreement on Economic and Technical Cooperation Between China and Ghana, Aug. 18, 1961, id. at 250; Agreement on Economic Assistance Between China and Cambodia, June 21, 1956, 5 PRC TREATY SERIES 109, and its implementation agreement of the same date, id. at 111.

155 E.g., Agreement on Economic and Technical Cooperation Between China and Syria, Feb. 21, 1963, 12 PRC TREATY SERIES 171; Agreement on Economic and Technical Cooperation Between China and Mali, Sept. 22, 1961, 10 PRC TREATY SERIES 333; Agreement on Economic and Technical Cooperation Between China and Guinea, Sept. 13, 1960, 9 PRC TREaty Series 80.

${ }_{150}$ E.g., Agreement Between China and Mali, supra note 155; Agreement Between China and Ghana, supra note 154. 
living of these personnel must not be higher than that of local personnel at the same level or grade. ${ }^{157}$

(4) Separate agreements are to be concluded concerning the details of assistance, such as the type of commodities, equipment and machines to be shipped from China; specifications on factories or bridges to be built; the number of technical experts to be sent; the detailed routes of a highway to be constructed. These agreements, however, are not published. ${ }^{158}$

In addition to the above loan and aid agreements, mention may be made of the Chinese establishment of joint shipping lines with Albania and Tanzania as another form of assistance. Under a SinoTanzanian agreement announced in Dar-es-Salaam on July 7, 1966, for example, a joint shipping line was established to operate between China and Tanzania. The line would begin with two 10,000-ton vessels and with an initial capital of $£ 1,500,000$, all supplied by China. One-half of the capital, however, would represent Tanzania's share, which China would make available as an interest-free loan repayable from the shipping line's profit over a ten-year period beginning in 1977.159 If the Albanian model is followed, there will be an annual meeting of the board of directors, whose decisions will constitute a semi-official agreement between the two countries. ${ }^{100}$

Since the economic aid agreements could present an opportunity for judging China's actions when she is dealing from a position of strength, a review of these agreements would be particularly significant for the present study. In view of the nonpublication of detailed aidimplementation agreements and an understandable reluctance on the part of aid recipients to look a gift horse in the mouth, however, a systematic evaluation of Chinese compliance with respect to the aid agreements could not be undertaken at this time.

157 See Agreement Between China and Nepal, supra note 154; Agreement Between China and Ghana, supra note 154; Agreement Between China and Guinea, supra note 155 .

158 Recent discontinuance of the Chinese aid program in Burma in the aftermath of Burmese rioting in which more than 50 Chinese were reportedly killed (including a textile expert on Chinese Embassy premises) brought to light certain information concerning the nature of the program. Chinese aid equivalent to $\$ 84,000,000$ had been provided to Burma in the form of an interest-free loan for materials and technical services. Under this assistance, a river bridge and a sugar refinery have been completed, while work has begun on a paper mill, another bridge, a plywood mill and a textile mill. Plans were also made for an hydroelectric plant, a bicycle tire plant and the expansion of a small steel mill. Some 390 Chinese aid technicians were reportedly involved in the various projects. That Burma retained control over the content and direction of the programs may be seen by the fact that General $\mathrm{Ne}$ Win had vetoed Chinese aid projects aimed at improving communications between Burma's northern regions and China. See N.Y. Times, July 8, 1967, at 3, col. 1; July 9, $1967, \S 4$, at 3 , col. 1 ; July 12,1967 , at 10 , col. 5 ; Nov. 1, 1967, at 1, col. 3 .

1591966 Kensing's ConteMr. ARCHives, July 2-9, at 21488A.

160 See reference to the fourth such agreement between China and Albania in JEN-MIN SHOU-TS'E (People's Handbook) 266 (1965). 


\section{G. Cultural Agreements}

For the promotion of mutual understanding and goodwill, the $\mathrm{PRC}$ has entered into an extensive network of cultural agreements with friendly states providing for the exchange of students, scholars, technical experts and newsmen as well as publications and information. Indeed, such exchanges exist even in the absence of a cultural agreement and even between states not recognizing each other.

Among the agreements first concluded by the PRC and now a subject of bitter controversy were those with the Soviet Union: Agreement on Admission of Chinese Citizens into Higher Soviet Institutions of August 9, 1952; ${ }^{161}$ Agreement on Broadcasting Cooperation of August 21, 1954; ${ }^{162}$ Scientific and Technical Cooperation Agreement of October 12, 1954; ${ }^{163}$ Agreement on Cultural Cooperation of July 5, $1956 .^{104}$ In addition, there are, where applicable, annual or semiannual implementation agreements, the latest of which is the Protocol of the 15th session of the Sino-Soviet Committee for Scientific and Technical Cooperation, signed on November 6, 1966 in Peking. ${ }^{165}$

In view of the current controversy in which Peking and Moscow have accused each other of violating their cultural cooperation agreements, the major provisions of the 1956 agreement may be briefly described: the agreement calls for an exchange of students, researchers and teachers; the promotion and development of direct contacts between higher institutions; and exchange of educational experiences, materials and publications. (Article 2.) Detailed annual plans for implementation, including annual budgets, are to be drawn up by October of each preceding year through diplomatic channels. (Articles 3 and 4.) The agreement was to be of five-years' duration, and to be automatically renewed if no notice for its termination was received six months prior to the termination date. (Article 5.) It may be noted that this kind of long-term agreement supplemented by annual implementation agreements is a common pattern in cultural agreements concluded by the PRC.

Like many other controversies between the Soviet Union and the $\mathrm{PRC}$, the cultural dispute has its origin in the ideological cleavage of the late nineteen fifties, but was exacerbated by the Great Proletarian Cultural Revolution. The Revolution caused a one-year shut-down of

1612 PRC TREATy SERIES 179.

1623 PRC TREATY SERIES 157.

$163 \mathrm{Id}$. at 170 .

1645 PRC Treaty Sertes 152.

165 Hsinhua News Agency Release, No. 6506, Nov. 7, 1966, at 2 (Eng. ed.); U.S. Consulate General, Hong Kong, Survey of China Mainland Press No. 3817, Nov. 8, 1966, at 41 . 
all institutes of higher learning in China to enable students to participate in Red Guard activities and to revamp the "bourgeois-infested" educational system throughout China. This inevitably affected all foreign students in China, who suddenly found themselves without schools to attend. Since there was no role for them to play in the cultural revolution, arrangements were made for them to suspend their studies for a year, while those nearing completion of their studies were to be graduated ahead of schedule. ${ }^{106}$ The Soviet Union, however, considered the Chinese action to be a breach of the cultural agreement and decided not only to recall its students from China, but also to expel Chinese students from the Soviet Union. The Soviet expulsion of some sixty-five Chinese students was in turn protested by China as a "grave incident," in which the Soviet Government has "flagrantly violated the agreement on cultural cooperation between China and the Soviet Union." 107 In elaborating on this at a Peking rally to welcome home the expelled Chinese students, China's Vice Minister of Higher Education Tuan Lo-fu stated:

The great proletarian cultural revolution has been developing vigorously in China and, in the course of it, all institutes of higher learning have discontinued their course. It has not been possible to arrange separate courses for foreign students in China. Therefore we decided that all the students from other countries would have to stop their studies for a year, while those about to graduate could do so ahead of schedule. In each case the time of graduation for the Soviet students, was to be settled after consultation with the Soviet side. We set no time limit as to when the Soviet students should leave China for home. The Soviet Union is not carrying on a great cultural revolution. Its schools have not stopped their courses and students from various countries in the Soviet Union are carrying on their studies as usual. Yet without consulting with the Chinese side, the Soviet Government unilaterally decided to drive out all the Chinese students studying in the Soviet Union. What else is this other than a deliberate action to undermine the relations between China and the Soviet Union and stir up further antiChinese sentiment? ${ }^{168}$

Some East European countries, such as Hungary, ${ }^{169}$ have followed the Soviet position that the Chinese action constituted a violation of their cultural agreements, hence justifying retaliation. The question

106 N.Y. Times, Oct. 24, 1966, \$1, at 1, col. 6 .

107 Id.

108 Hsinhua News Agency Release No. 6506, Nov. 6, 1966, at 1a; U.S. Consulate General, Hong Kong, Survey of China Mainland Press No. 3818, Nov. 9, 1966, at 31. 169 Japan Times, Nov. 27, 1966, at 2, col. 1. 
may be raised as to whether the Chinese action indeed constituted a treaty violation or was merely a case of temporary impossibility of performance justifying a suspension of the operation of the treaty. The latter view appears to be supported by the International Law Commission's Law of Treaties as adopted in 1966:

Article 58. Supervening impossibility of performance

A party may invoke an impossibility of performing a treaty as a ground for terminating it if the impossibility results from the permanent disappearance or destruction of an object indispensable for the execution of the treaty. If the impossibility is temporary, it may be invoked only as a ground for suspending the operation of the treaty. ${ }^{170}$

It may be noted that, in his Fifth Report on the Law of Treaties, ${ }^{171}$ Sir Humphrey Waldock, the Special Rapporteur, proposed the inclusion of an additional paragraph which would have denied a state the right to invoke the above provision "if the impossibility of performance is the result of a breach of the treaty by the party invoking such impossibility." The Commission, after a lengthy debate in which the Soviet member joined with several others in opposing Sir Humphrey's proposal, decided to drop the qualifying paragraph. ${ }^{172}$ Their opposition was based on grounds of impracticality and the view that the qualifying provision would lie more properly within the purview of State responsibility. It is significant to note, however, that the Commission decided to retain a similar qualifying paragraph in Article 59 (Fundamental Change of Circumstances). ${ }^{173}$ Discussing the need for equitable adjustment in the case of a temporary suspension of a treaty which has been partially executed, the Commission called for application of the principle of good faith. ${ }^{174}$

Applying the above principles to the case at hand, it would appear that the closing of all universities in China for one year-a move directed fundamentally at Chinese students and only incidentally affecting the Soviet and other foreign students-would constitute grounds for temporary impossibility of performing a student-exchange treaty because of the disappearance of "an object indispensable for the execution of the treaty." Whether the temporary closing of the universities was wise or desirable under the Cultural Revolution is immaterial;

170 Emphasis added. See International Law Comm'n, Draft Articles on the Law of Treaties and Commentaries, 21 U.N. GAOR, Supp. 9, at 84, U.N. Doc. A/6309/Rev. 1 (1966).

171 U.N. Doc. A/CN.4/183/Add. 3, at 6 (1966).

1721 Y.B. INT'L L. COMMN'N 67-75, 129-30, U.N. Doc. A/CN.4/SER.A (1966). 173 See Art. 59(2) (b) of Draft Articles, supra note 170, at 82. 174 See Art. 66 Commentary (4) of Draft Articles, supra note 170, at 93. 
that the closing was a proper exercise of national sovereign power cannot be questioned. By signing a student-exchange agreement, the PRC did not sign away its power to close all its universities during national emergencies. The Soviet Union might legitimately call upon the PRC to assume a greater share of financial responsibility consequent upon the withdrawal of Soviet students. However, the Russian decision to expel the Chinese students appears to fall short of the "good faith" requirement. ${ }^{175}$

\section{H. UNICEF}

The substantive part of the present study concludes with a discussion of the relationship between the United Nations International Children's Emergency Fund (UNICEF) ${ }^{176}$ and the PRC and its precursors. UNICEF maintained a working relationship with Chinese Communist authorities for more than a year, based upon an exchange of letters of mutual understanding in Shihchiachuang in August, $1948,{ }^{177}$ and continuing until after the establishment of the PRC. ${ }^{178}$ Experience gained from this period might be useful in future dealings between the United Nations and the PRC.

UNICEF was established for the benefit of children and adolescents of countries which were victims of aggression or which had been receiving help from UNRRA, and for child health purposes generally. ${ }^{178}$ Its guiding principle was one of nondiscrimination, ${ }^{180}$ and assistance could be rendered to states not members of the United Nations. Before aid will be granted, however, prior agreements must be entered into by UNICEF and the recipient state concerning matters of supply, distribution, contribution, control and supervision.

175 It may be noted that, although the Chinese decision also affected students in China from other countries, Chinese students in those countries have not been expelled, but ostensibly have returned to China to participate in the Cultural Revolution. For a discussion of Asian and African students affected by the Chinese decision, see Réalités Cambodgiennes (Phnom-Penh), Sept. 30, 1966, at 2, col. 1. For the story of the latest return of 70 students from Algeria, see Japan Times, Feb. 8, 1967, at 4 , col. 8 .

176 UNICEF was established pursuant to G.A. Res. 57 (I), 1 U.N. GAOR 1157, U.N. Doc. A/230 (1946). By G.A. Res. 802 (VIII), 8 U.N. GAOR 237 (1953), U.N. Doc. A/L. 163, the name of the organization was changed to the United Nations Children's Fund, retaining the symbol UNICEF. See 1953 YEARBOoK OF THE UNITED NATIONS 467-68.

177 See text accompanying notes 182-84 infra.

178 The Shihchiachuang Understanding was terminated on December 30, 1949. Although UNICEF personnel in Peking were given until the end of January, 1950, to "wind up all their affairs," see New China News Agency, Daily News Release No. 244, Jan. 1, 1950, relations with Peking authorities continued intermittently until the departure of the last UNICEF officer from Peking in January, 1951. See note 187 infra.

179 See 1946-47 YEARBOOK OF THE UNITEd Nations 163.

180 See G.A. Res. 57 (I), 12 (b) (ii), 1 U.N. GAOR 1157, U.N. Doc. A/230 (1946), in 1946-47 YEARBOOK OF THE UNITED NATIONS 163. 
In February 1948, Dr. Marcel Junod was sent to China by UNICEF to reach an agreement with the Nationalist Government. A standard UNICEF Basic Agreement was signed in Nanking on May 21,1948 , establishing a program for feeding and clothing needy children in several large cities.

Since the above agreement could not apply to Communist-held territories, the Executive Board of UNICEF adopted a resolution on April 28, 1948, which set aside an initial allocation of $\$ 500,000$ for the establishment of a program "in areas not under the direct control of the Government." 181 Dr. Leo Eloesser, head of UNICEF's North China Field Team (NCFT) was to negotiate with the Communist authorities for a letter of understanding incorporating basic UNICEF principles. After a series of discussions in Shihchiachuang, the Headquarters of the China Liberated Areas Relief Association (CLARA), ${ }^{182}$ in mid-August, 1948, a Letter of Understanding bearing the seal of Tung $\mathrm{Pi}-\mathrm{wu},{ }^{183}$ chairman of CLARA, and signed by General Wu Fu-sun, Secretary-General of CLARA, was obtained by UNICEF's team on August 30th. The letter accepted UNICEF's proposal dated August 27 th, ${ }^{184}$ which had contained the following key provisions:

1). The UNICEF program shall be undertaken for the benefit of needy children and expectant and nursing mothers without discrimination because of race, creed or political belief, and the supplies and personnel furnished by UNICEF shall not be used for any other purpose.

2). Supplies imported by UNICEF shall be matched by CLARA by making available such personnel, warehousing, services, internal transportation and miscellaneous equipment as are necessary to the carrying out of the program. In anticipation of supplies to be received from UNICEF a plan of operations shall be drawn up and mutually agreed upon, indicating the method by which these supplies are to be used and designating the categories and approximate numbers of children and mothers who may be served under the program.

3). All supplies imported by UNICEF into the area shall remain the property of UNICEF and shall be utilized

1817 U.N. ECOSOC 6, U.N. Doc. E/ICEF/59 (1948).

182 CLARA had participated in tri-partite relief projects with UNRRA and CNRRA (Chinese National Relief and Rehabilitation Agency-the Nationalist counterpart of CLARA). Its personnel were withdrawn from Tientsin and Shanghai following the failure of peace negotiations between the Nationalists and Communists. It was superseded in the spring of 1950 by the People's Relief Administration of China, headed by Mme. Sun Yat-sen, with General Wu Yun-fu as Secretary-General. $183 \mathrm{Mr}$. Tung was the lone Communist member of the Chinese delegation to the San Francisco Conference establishing the United Nations in 1945. See Doc. 639, $G / 3(2), 1$ U.N.C.I.O. Docs. 18 (1945). At present he is one of the two Vice Presidents of the PRC (the other being Mme. Sun Yat-sen).

184 The proposal was modeled upon an earlier UNICEF Basic Agreement with the Nationalist Government, May 21, 1948. 
under the supervision and control of UNICEF personnel until consumed or received by the end-user. In distributing or otherwise handling such supplies according to the mutually agreed upon Plan of Operations, CLARA shall be entrusted to act until the supplies are consumed or used. Distribution shall be free of charge to the end-users.

4). Expenses in local currency for housing, feeding and incidental expenses required by UNICEF personnel in the area will be met by CLARA; facilities for travel and transportation shall also be furnished.

5). Radio liaison with Hong Kong shall be maintained and UNICEF representatives shall be furnished facilities by the CLARA authorities to send plain messages necessary to the UNICEF program.

6). UNICEF personnel shall have all necessary freedom to supervise distribution of UNICEF supplies. The

UNICEF program shall enjoy full freedom of publicity. A program involving public health training and medical supplies was adopted on the basis of the above understanding. The medical supplies aspect soon became the subject of controversy, however, and increasingly strained relations between CLARA and UNICEF developed as the oft-delayed medical supplies began to arrive in North China in March, 1949.185 Disputes centered on the meaning of the ambiguous language of Paragraph 3 of the understanding which referred to "supervision and control" of the supplies. UNICEF emphasized that the supervision and control envisaged by the first part of Paragraph 3 was to extend both to utilization of supplies and to their distribution and handling. CLARA, stressing the latter part of the same paragraph, insisted, however, that the provision of Paragraph 3 that CLARA "shall be entrusted to act" with respect to distribution and handling was intended to bestow on CLARA absolute control over those processes, subject only to UNICEF supervision. The focal point of dispute became the location of warehousing facilities, with UNICEF insisting on Peking, because it was more easily accessible to NCFT personnel, and CLARA insisting on Tientsin, near the port of entry. Since neither side was willing to give in, UNICEF decided, in May, 1949, to suspend further shipments from Hong Kong to North China until the warehousing issue could be resolved-a decision regarded by CLARA as an attempt to coerce it into bowing to UNICEF's will. For the remainder of the year, only one shipment was made to North China and that shipment of supplies for the BCG laboratory was made were due to difficulties in procurement and shipping under civil war conditions. 
directly to the National Vaccine and Serum Institute in Peking, thus bypassing CLARA.

On September 22, 1949, General Wu Yun-fu, Secretary-General of CLARA, addressed a letter to UNICEF's representative in North China calling for a prompt resumption of shipments from Hong Kong to Tientsin, quick distribution of supplies already in North China and devotion of the balance of allocations for the purchase of supplies to combat the infectious disease kalaazar. Otherwise, CLARA would be "forced to reconsider the question of the continued validity of the Shihchiachuang Agreement." UNICEF's representative replied by reiterating the earlier positions regarding supervision and control of warehousing, and stating its readiness to withdraw from North China, unless CLARA observed the Shihchiachuang Understanding.

On December 30, 1949, three months after the establishment of the PRC, the Acting Secretary-General of CLARA, Hsiung Chin-ting, issued a statement ${ }^{186}$ declaring the abrogation of the Shihchiachuang

186 The text of the statement appeared in New China News Agency, Daily News Release, No. 244, Jan. 1, 1950 . It reads as follows:

The Shihchiachuang understanding was reached in conformity with the letter of Dr. Leo Eloesser, representative of the United Nations International Children's Emergency Fund in North China, dated August 27, 1948, and the reply by the China Liberated Areas Relief Association dated August 30, 1948. But after reaching this understanding, Dr. Leo Eloesser did not act according to its spirit. The main facts during the past year and more are as follows:

1. It was agreed upon by both parties that the first shipment of supplies should arrive by the end of December, 1948, but, in fact, this shipment did not arrive until March, 1949.

2. The first shipment of supplies received amounted to only US $\$ 105,000$ which was approximately one seventh of the stipulated amount of US $\$ 750,000$ (original amount of US\$500,000 plus a later increase of US $\$ 250,000$ ). During the nine months from March to December, 1949, no supplies whatsoever were received.

3. There were altogether 824 cases in the first shipment of supplies of which 304 cases were scott paper and cellulose tissue. These were not what we needed.

Under such conditions, we had several talks with Dr. Eloesser to seek an improvement of the situation. But he showed no intention of making any improvement.

Before Dr. Eloesser returned to the United States, we wrote to him on September 22 of this year, urging him to observe the spirit of the Shihachiachuang understanding by promptly shipping the supplies remaining in Hongkong to Tientsin and by purchasing with the remaining funds medicines for the treatment of kalaazar which we needed. We told him that the shipments of US $\$ 750,000$ 's worth of supplies should be completed by the end of December, 1949.

But Dr. Eloesser, in his reply letter dated September 24, 1949, utterly ignored the reasonable opinion, but on the contrary, he demanded that we accept what he called certain attached conditions. But he did not make clear what the contents of these so-called attached conditions were. According to the facts of the several talks we had with him, the attached conditions meant a long disputed condition which we could not agree to, namely the right of complete control over the distribution and storage of the incoming shipments of supplies. He further said that the United Nations International Children's Emergency Fund stood ready to withdraw its set-up in North China should we fail to accept the so-called attached conditions as stated in his letter. 
Understanding as a result of UNICEF's violations. In addition to objecting to UNICEF's positions concerning distribution and storage, it criticized UNICEF for the suspension of shipments, as well as the poor quality and small quantity of supplies already shipped.

It is clear that under the terms of Paragraph 3 of the understanding, title to all supplies was to remain in UNICEF until consumed or used. Indeed, with respect to ownership of the supplies, there was no disagreement between UNICEF and CLARA. Nor were there any reports of tampering with UNICEF labels on supplies shipped to North China or other interference with UNICEF's publicity activities as provided for by Paragraph 6 of the understanding.

It was also quite clear that, under Paragraph 3, utilization would be subject to UNICEF supervision and control. The fact that CLARA repeatedly urged UNICEF to agree to a rapid distribution of supplies already on hand is an indication that UNICEF's control over the utilization of the supplies was recognized by CLARA. It may be noted that UNICEF participated with CLARA and Ministry of Health representatives as late as December, 1949, in drawing up allocation plans for such supplies. They approved all allocations before releasing the supplies to a wide variety of nurseries, clinics, hospitals and the Tungchow training center. This participation took place even during the period when relations with CLARA were severely strained as a result of UNICEF's suspension of further medical shipments due to disagreement over warehousing.

At this point, Dr. Eloesser's real intention in consistently violating the Shihchiachuang understanding was laid bare. After his return to the United States, Dr. Eloesser made a statement saying that US\$750,000 had been spent in liberated China (according to the Lake Success despatch of November 5 in the Shanghai North China Daily News). This is entirely inconsistent with facts.

Dr. Eloesser, representing the United Nations International Children's Emergency Fund, insisted on his unreasonable conditions and violated the Shihchiachuang understanding, thus depriving it of any practical significance. Because of this, I have to make the following solemn statement:

From now on we are no longer bound by the Shihchiachuang understanding. At the same time, we must point out: facts have proved that the supplies left and stored in Hongkong by Dr. Eloesser were not intended to be shipped to the liberated areas of China, but were to be used for bribing the Chinese people into bowing to American imperialism. We refuse to be bought and we do not bow to American imperialism, so he will "redistribute elsewhere" that shipment of supplies.

In order to facilitate the winding up of the branch office in North China of the United Nations International Children's Emergency Fund, we permit its twelve staff members in Peking to wind up all their affairs by the end of January, 1950. 
With respect to the distribution and handling of supplies, however, the understanding is far from clear. As far as can be ascertained, UNICEF's right to supervise the distribution and handling of supplies was never challenged by CLARA. Indeed, CLARA suggested that UNICEF send a representative to the proposed central warehouse in Tientsin. However, all attempts by UNICEF to control distribution and handling (including warehousing) were opposed by CLARA on the ground that Paragraph 3 entrusted to CLARA alone the right to distribute or otherwise handle the supplies until consumed or used, and that Paragraph 6 conferred upon UNICEF personnel the right to "all necessary freedom to supervise distribution of UNICEF supplies." On the whole, the text could support CLARA's distinction between control over utilization of the supplies and their distribution and handling, a distinction UNICEF sought to blur by its insistence on control over both. Moreover, CLARA was obliged by Paragraph 2 to make available not only warehousing, but also "such personnel, . . . services, internal transportation and miscellaneous equipment as are necessary to the carrying out of the program." Thus, any argument for giving UNICEF control over warehousing under the circumstances also would grant to UNICEF control over the personnel, services, internal transportation and equipment made available by CLARA. If concessions of such a serious nature, affecting sovereign prerogatives, were intended, it surely ought to have been more clearly stated in the text of the understanding. It may be significant to note that no attempt to control the personnel or internal transportation provided by CLARA was ever made by UNICEF.

In any event, apart from any question of the proper construction of the language of the agreement, UNICEF's decision to suspend medical shipments to China because of the disagreement over warehousing must be considered rather drastic in the absence of any prior abuse or misappropriation of UNICEF supplies by CLARA, any doubts about CLARA personnel's honesty and integrity, and the ambiguous grounds for UNICEF's control over warehousing under the Shihchiachuang Understanding. Subsequent interruption of the flow of supplies over a period of more than half a year, despite repeated protests, well might constitute a legitimate ground for termination of the Understanding by China. The irony of the situation is that after the termination of the Understanding, the flow of supplies was resumed-and on an "unconditional" basis without any control or supervision by UNICEF in China.

In an attempt to continue relations with the PRC, UNICEF announced in January, 1950, its willingness to resume shipments and to send a representative to Peking to negotiate a Basic Agreement and 
draw up a program for utilizing the allocation to China of some seven million dollars. CLARA replied that it would accept UNICEF supplies now only on an "unconditional" basis-without any commitment as to the use of supplies. Further discussion could take place only after their arrival. Some $\$ 300,000$ worth of supplies were shipped shortly afterwards and turned over to CLARA by UNICEF in Tientsin. ${ }^{18 \tau}$

Space permits only a brief discussion of CLARA's conduct in relation to the remaining provisions in the Shihchiachuang Understanding. In contrast to the medical supply program, the training program proceeded smoothly, with Dr. Eloesser inaugurating the first UNICEFsponsored People's Health Workers Training Course for twenty students in a village near Shihchiachuang on November 20,1948. Its object was "to train in the essential rudiments of sanitation, health and midwifery a large number of people." 188 Promising graduates of each class were to be selected to serve as instructors in additional training centers to be established. By the time the course had ended on February 12, 1949, additional major cities in North China had been taken over by the Communists. Consequently, the training center was relocated in Tungchow, near Peking, and the second course, with an enlarged enrollment of 80 and a longer training period, began on July 16, 1949 . This course, blessed with newly arrived UNICEF

187 UNICEF's subsequent relations with Peking, though interesting, must be left out of the present study inasmuch as they were no longer based upon the Shihchiachuang Understanding. Subsequent responses from CLARA and other Chinese authorities to UNICEF inquiries and offers of assistance were usually oral and were negative. An exception occurred in early summer, 1950, when Peking officials drew up lists of requirements with UNICEF medical advisers in response to UNICEF's offer to secure anti-kalaazar medicines and supplies, using the unprocured balance of the original Shihchiachuang allocation. However, they declined UNICEF's offer of technical assistance and request for an observer to visit the field of operations. Shipment arrived during the winter of 1950-51.

On August 25, 1950, Premier Chou En-lai cabled the Chairman of the UNICEF Executive Board, nominating General Wu Yun-fu as the PRC's representative on that Board. At its meeting in later November, 1950, the vote on the motion to seat the Peking nominee resulted in a tie. A second vote was taken, and the result was again a tie. The motion therefore failed of adoption. UNICEF then decided to suspend "temporarily" its China Mission and recall its staff. The last staff member in Peking departed in January, 1951.

Similarly omitted from the study are UNICEF's relations with Chinese Communist authorities in the newly occupied cities of Nanking and Shanghai, where UNICEF had conducted large-scale feeding and clothing programs under the 1948 Basic Agreement with the Nationalist Government. The Communist authorities refused to recognize the UNICEF-Nationalist Chinese agreement, and considered the Shihchiachuang Understanding inapplicable to Nanking and Shanghai both geographically and because the programs in those cities had covered feeding and clothing. Consistent with this stand, Chinese authorities in Nanking and Shanghai considered UNICEF personnel as ordinary civilians without any immunity. One of them subsequently experienced great difficulty in obtaining an exit permit and was not permitted to depart until April, 1951.

188 For this purpose Dr. Eloesser wrote a 164-page text with index and appendices entitled, First Aid: EMrergency TrEatMinnt of INJURIEs; Preparation of Dressings and Surgical Supplies: A Short Manual for Peorle's Healti WorkERS (Pen Tu Chuang, 1949). 
drugs and medical equipment and additional training personnel, proved, however, to be the last held under UNICEF's auspices. Following the abrogation of the Shihchiachuang Understanding in late 1949, UNICEF technical personnel remained at CLARA's request until the end of the course in late January, 1950. Building on the foundations already laid, a third course was held without UNICEF personnel, but with UNICEF medical supplies and equipment. The training project had proved its worth and had contributed in no small measure to the vast expansion of public health services throughout China in subsequent years. It may be stressed that in carrying out the training program, both in Shihchiachuang and in Tungchow, an excellent working relationship was maintained between UNICEF and the Chinese Communist health authorities. Both the letter and spirit of the Shihchiachuang Understanding appear to have been lived up to by all parties concerned. Thus, UNICEF was able, within a short span of time and with meager resources, to build a foundation for public health training to the great benefit of the Chinese people.

It also will be recalled, that Paragraph 5 obligated CLARA to provide UNICEF with special radio equipment and facilities in Shihchiachuang for communication with Hong Kong. This was complied with, and the equipment was not removed for other purposes even after the departure of UNICEF personnel for Peking, until UNICEF indicated, in response to a specific inquiry, that it no longer needed the equipment.

Of considerable interest is CLARA's policy in regard to Paragraph 4 of the Understanding, which provided that "Expenses in local currency for housing, feeding and incidental expenses required by UNICEF personnel in the area will be met by CLARA." UNICEF had proposed a per diem allowance equal in local currency to $\$ 1.60$ for each Western employee living alone and a higher flat rate of $\$ 130$ for each employee living with dependents. CLARA rejected the flat rate on the ground that subsistence and billeting for dependents were not provided for in the Understanding. It did accept, on the other hand, the per diem rate of $\$ 1.60$ for both foreign and Chinese personnel of UNICEF, thus placing them on a footing of complete equality, and making no distinction between salary for local personnel and subsistence for foreign personnel. It may be noted that this rate was from five to eight times higher than the average salary of a CLARA employee. CLARA, thus, tolerated a discrepancy in pay between its personnel and UNICEF's Chinese personnel, but insisted upon parity of treatment for all UNICEF personnel, whether foreign or Chinese. ${ }^{189}$

189 This is consistent with the Chinese pay policy discussed in the text accompanying note 157 stspra. 


\section{ConCLUSIONS}

Despite the tentativeness and incompleteness of the present study, several broad conclusions may be drawn. In place of the picture of mainland China bent upon a conquest of its neighbors, bullying the weak and the small, it appears that with the exception of her boundaries with India and Russia, all other boundaries of China have been delineated, in a manner which is often favorable to China's neighbors. The PRC has, on the whole, complied with the Korean Armistice Agreement and unilaterally withdrew its troops from Korea in 1958 when a simultaneous withdrawal of all foreign forces from Korea proved impossible. There has been no published evidence of the presence of Chinese troops outside China's soil.

Although under international law a nation need not enter into a fisheries agreement with a state which does not recognize it, the PRC has concluded such agreements with Japan, to Japan's advantage. With respect to trade agreements, except for recent difficulties in connection with the Cultural Revolution, the PRC has enjoyed an excellent reputation for meeting its obligations. The consensus appears to be that, while negotiation with Peking is not always an easy matter, once an unambiguous agreement is reached, compliance likely will follow. Since China is not unduly concerned with the form an agreement takes, so long as it expresses the will of the parties, Peking has concluded many agreements on the nongovernmental level and complied with them as treaties.

Reference was made earlier to the Chinese relinquishment of a mining concession in Burma on the ground that it was incompatible with the principles of the sovereign equality of states. ${ }^{190}$ The question may be raised whether this was but an isolated instance, or whether from this there may be deduced a pattern of behavior against the imposition of unequal treaties by China upon its weaker neighbors. While generalization is difficult, the following case may shed some light on the question.

Immediately following World War II, Nationalist Chinese troops entered the northern half of Indo-China (north of the 16th parallel) for the purpose of effecting the Japanese surrender and maintaining order and security. After repeated attempts by France to resume control of northern Indo-China, a Franco-Chinese exchange of letters finally took place on February 28, 1946, providing for the withdrawal of Chinese forces by March 31, 1946. ${ }^{191}$ Simultaneously, however, an

191 Echange de lettres relatif a la rélève des troupes Chinoises par les troupes françaises en Indochine du Nord, Feb. 28, 1946, in ChINese Ministry of Foreign Affatrs, Treaties Between the Republic of China and Foreign States (19271961), at 150-52 (1963). 
agreement was signed governing Sino-Indo-Chinese relations. ${ }^{192}$ Of special interest is Title II, which provided:

Article 1. The French Government shall reserve in the port of Haiphong a special zone, including the warehouses, berths and, if possible, the wharves necessary for the free transit of merchandise on the way from or to China. The Chinese customs authorities shall be responsible for customs supervision in the zone and the French authorities shall be responsible for all other matters, in particular public safety and health.

Article 2. Merchandise on the way from or to China's territory, and transported over the railways of Tonkin, shall pass free of duty between the Sino-Indochinese frontier and the zone reserved for Chinese international transit in the port of Haiphong. Such merchandise shall be transported in wagons which shall be sealed at the time of their departure by the Chinese customs authorities.

Article 3. Merchandise on the way from or to China, and transported by railway in Indochina, shall be exempt from all transit dues or taxes. ${ }^{193}$

While it is not unusual for states to accord customs exemptions to traffic in transit, ${ }^{194}$ the unreciprocated right to create a special zone in Indochina with the necessary warehousing and docking facilities under the exclusive customs jurisdiction of China may be regarded as a right flowing from an unequal treaty. Would the People's Republic of China insist upon this special right in its relations with the Democratic People's Republic of Viet-Nam?

The PRC Treaties Series does not contain any treaty on this subject, and inquiries to the French Embassy and the South Vietnamese Embassy in Tokyo proved equally fruitless. However, through the embassy of a third state which maintains a Consulate General in Hanoi, the author was able to obtain the following information: on April 12, 1957 , an agreement was signed between representatives of the Warehousing and Transport Bureau of the PRC Ministry of Commerce and the Railway Administration of North Viet-Nam providing for the customs-free transit of not more than 5,000 metric tons per month of non-military goods through the territory of the Democratic People's Republic of Viet-Nam between China's southwestern Yunnan province and other parts of China. The prescribed routes were either by land via Lao Cai in Viet-Nam to or from Pinghsiang in China's Kwangsi

192 Accord Franco-Chinois sur les relations Sino-Indochinoises, Feb. 28, 1946, in id. at $146-48$.

193 English transiation in 14 U.N.T.S. 137.

104 See, e.g., Art 3 of the 1965 Convention on Transit Trade of Land Locked States, U.N. Doc. TD/TRANSIT/9, July 9, 1965. 
province, or by sea via Haiphong and a Chinese port. Significantly omitted was any provision concerning a special zone in Haiphong with the necessary warehousing and docking facilities under Chinese customs jurisdiction. ${ }^{195}$

What are the implications of the foregoing discussion for the future? Rather than attempting any answer, the following questions may instead be posed: In the absence of evidence concerning Chinese noncompliance based on a review of observable and selected treaties and informal agreements, and in view of at least one instance of Chinese renunciation of special rights derived from unequal treaties, would it not be in the world interest to place Peking under the regime of as many treaties as possible, including the Charter of the United Nations, the many multilateral conventions concluded under United Nations auspices such as the Geneva Conventions on the Law of the Sea and the two Vienna Conventions on Diplomatic and Consular Relations and the prospective disarmament treaties including one to prevent the spread of nuclear weapons? ${ }^{196}$ In the face of Peking's emphasis on treaty-centered international law, would it not be desirable for China to participate in the progressive development of international law and its codification in the International Law Commission? Would not international law be made more effective if it were accepted and complied with by a state whose population constitutes a quarter of humanity? Indeed, can "international law" be properly so-called if a quarter of the world's population is outside its pale? Of more immediate relevance, what would be the impact, if any, of a treaty-bound China upon future policies in Viet-Nam? ${ }^{197}$

195 The text of the agreement is summarized in New China News Agency, April 12, 1957; U.S. Consulate General, Hong Kong, Survey of China Mainiand Press, No. 1512, April 17, 1957, at 58.

196 For a discussion of this subject between President Johnson and Premier Ion Gheorghe Maurer of Roumania, see N.Y. Times, July 11, 1967, at 1, col. 8. See also letter to President Johnson by the Educational Committee to Halt Atomic Weapons Spread, which is headed by Arthur Larson, Director of the Rule of Law Research Center, Duke University, summarized in N.Y. Times, July 11, 1967, at 14, col. 5; UNA-USA, StOpPING THE SPREAd OF NUClEAR WEAPONS (1967); Draft Treaty on the Non-proliferation of Nuclear Weapons submitted by the U.S. and the Soviet Union at the Eighteen Nation Disarmament Conference on Aug. 24, 1967, text reproduced in id. at 40 .

Refusal by Peking to sign the 1963 test ban treaty may be viewed as indicating that China does not take lightly commitments to international agreements of this nature. See Leng, supra note 1 , at 116.

197 It may be appropriate to recall a recent statement by Secretary of State Rusk:

If there were a mainland China that made it clear it would live in peace with its neighbors, our presence in Asia, in any special sense, would be irrelevant. The American people would be content to tend to their own problems and leave the rest of the world alone. We are basically isolationist in that sense.

Moskin, Our New Western Frontier, Look, May 30, 1967, at 46. He went on to predict: "It's going to be useful for some time to come for American power to be able to control every wave of the Pacific, if necessary." Id. 
The present study will not be complete without an urgent plea for a redoubled effort towards a systematic study of the Chinese concepts and practice of law, both domestic and international. The present study has barely scratched the surface of Chinese practice in international law. Peking's concept of what constitutes an intervention in the domestic affairs of another nation, for example, must be thoroughly examined in view of the inclusion of a nonintervention clause in many of its treaties ${ }^{198}$ and the recent expulsion of its personnel from several African states for having allegedly intervened in their domestic affairs. It may be noted that this subject of nonintervention is more complex than is immediately apparent, and remains to be codified even after three sessions of the United Nations Special Committee on Principles of International Law concerning Friendly Relations and Co-operation among States. ${ }^{199}$

The PRC's role in the Geneva Conventions on Indo-China and Laos also needs to be analyzed once the dust has settled. A study of the background and character of recent diplomatic and consular incidents involving British, ${ }^{200}$ Dutch, ${ }^{201}$ French ${ }^{202}$ and

See also Secretary Rusk's statement at a news conference that American national security is at stake in South Viet-Nam because "within the next decade or two, there will be a billion Chinese on the mainland, armed with nuclear weapons, with no certainty about what their attitude towards the rest of Asia will be." New York Times, Oct. 13,1967 , at 14 , col. 1 .

198 See note 10 supra.

199 At the 1964 Mexico City Conference of the Special Committee, for example, there were serious differences of opinion on the definition of "intervention." See SPECIAL COMM. ON PRINCIPLes of INT'L LAw, REPORT CONCERNING FRIENDLy RELations and Co-operation among States, 109-41, U.N. Doc. A/5746 (1964); McWhinney, The "New" Conntries and "New" International Law: The United Nations" Special Conference on Friendly Relations and Co-operation among States, 60 AM. J. INT'L L. 1, 21 (1966); Lee, The Mexico City Conference of the United Nations Special Committee on Principles of International Law and Co-operation among States, 14 INT'x \& COMP. L.Q. 1304-06 (1965).

Attempts to obtain a consensus at two subsequent sessions of the Special Committee were equally unsuccessful. See Spectal CoMM. ON PRINCIPLes of INT'L LAw, Report Concerning Friendly Relations and Co-operation among States 124-60, U.N. Doc. A/6230 (1966); id. at 135-63, 210, U.N. Doc. A/6799 (1967).

200 Chinese demonstrators in Peking barred D. Hopson, British Chargé d'Affaires, from leaving for a trip, and in Shanghai manhandled $R$. Whitney, a first secretary, and $\mathrm{P}$. Hewitt, a consular officer, whose home was reportedly ransacked. The demonstrations were inspired by alleged British mistreatment of Chinese workers in Hong Kong. See N.Y. Times, May 16, 1967, at 1, col. 5; May 17, 1967, at 1, col. 5; May 25,1967 , at 1 , col. 3.

201 The PRC declared G. J. Jongejans, the Netherlands Chargé d'Affaires in Peking, persona non grata in retaliation for the Netherlands expulsion of $\mathrm{Li} \mathrm{En-chiu,}$ the Chinese Chargé d'Affaires, as persona non grata. Peking additionally held Jongejans as a hostage for the safe return of eight Chinese technical experts detained in The Hague in connection with the death of a Chinese engineer. Jongejans and the Chinese experts were eventually released after almost half a year's detention. See N.Y. Times, July 19, 1966, at 6 , col. 2 ; July 20, 1966, at 7, col. 1; July 23,1966 , at 2 , col. 4; Jan. 1, 1967, at 11, col. 1 .

202 Robert Richard, Commercial Counsellor of the French Embassy in Peking, was pulled from his car by demonstrators outside the Embassy and forced to stand in below-freezing cold for nearly seven hours for having allegedly struck three persons 
Soviet ${ }^{203}$ personnel may shed valuable insight on Peking's attitude towards customary international law, since the 1961 Vienna Convention on Diplomatic Relations and the 1963 Vienna Convention on Consular Relations lack binding force vis-à-vis Peking. The same holds true with respect to the Sino-Indian border conflicts in the absence of a boundary treaty. Also of interest are the effects, if any, of the tributary system that existed in the Confucian family of nations upon the PRC's relations with China's erstwhile vassal states.

Recent anti-Chinese riots and demonstrations in several Asian countries with attendant loss of Chinese lives and property have led Peking to make a number of significant pronouncements concerning the rights of overseas Chinese under international law and practice. ${ }^{204}$ Would Peking's concept of State responsibility towards aliens and their properties hold true when the PRC is the accused instead of the accuser? ${ }^{205}$ Would the doctrine of estoppel apply? These are questions pregnant with implications.

Above all, it should be realized that the Western concept of law is very different from that of China, dichotomized as it has been between $l i$ and $f a .^{206}$ In the event of a conflict, $l i$ usually prevails over $f a$, even in today's mainland China where Mao's " $l i$ " is being actively

with his car. He was released after a three-hour interrogation by military police. Anti-French demonstrations were held in protest against the arrest and alleged maltreatment of Chinese students trying to march on the Soviet Embassy in Paris. See N.Y. Times, Feb. 2, 1967, at 1, col. 2.

203 For stories of repeated Red Guard demonstrations against the Soviet Embassy in Peking for alleged brutality inflicted upon Chinese students in Moscow, see N.Y. Times, Nov. 27, 1966, at 19, col. 1 ; Jan. 30,1967 , at 3 , col. 1 ; Jan. 31,1967 , at 5 , col. 4.

204 For Peking's protests to Indonesia on treatment of Chinese, see PekIng REvIEw, No. 48, at 20-23 (1965) ; id. No. 12, at 5-6 (1966); id. No. 16, at 9-10 (1966). For protests to India, see 9 CHUNG-HUA JEN-MIN KUNG-Ho-KUo TUI-WAI KUAN-HSI WEN-CHIEN CHI, supra note 39, at 127-29, 161-62, 209-10; Chou Ken-shen, The Prosecution of Chinese Nationals and Infringement upon Their Rights and Interests by the Indian Government are Serious Violations of International Law, Jen-min Jih-pao, Jan. 22, 1963. For protests to Burma, see N.Y. Times, July 8, 1967, at 3, col. 1.

205 During the early 1950's there were many instances of expulsion, detention or imprisonment of aliens and de facto confiscation of their properties through such devices as enforced payments of back taxes and employees' severance allowances. See, e.g., Government Administrative Council, Decree for the Expropriation of the Asia Petroleum Co. Properties (British), April 30, 1951, in Chung-Yang Jen-Mrin CHEN-FU FA-LING HUI-PIEN (Collection of Laws and Decrees of the Central Government) 445 (1951) ; A. Bonnichon, LAW in Communist China (1956); U.S. Dep't of State, Conduct of Comarunist China (printed for use by the House Comm. on Foreign Affairs, 88th Cong., 1st Sess., 1963) ; U.S. LIBRARY of Congress LegisLatTVE Refrerence Service, Exproprtation of Amirrican-Owned Property by Foreign Governarents in the Twenteth Century 16 (prepared for the House Comm. on Foreign Affairs, 1963).

In the hope that there will be eventual compensation for American claims, Congress passed Pub. L. No. 89-780, 80 Stat. 1365 (Nov. 6, 1966) (An Act to amend title $V$ of the International Claims Settlement Act of 1949 (22 U.S.C. \$ 1643) to provide for determination of the amounts of claims of nationals of the U.S. against the Chinese Communist regime).

208 Roughly translated as "customary norms of behavior" and "enacted law," respectively. See note 23 supra. 
advanced through the Cultural Revolution to replace the century-old Confucian $l i$. Because of the predominance of $l i$, the study of Chinese law must be all-embracing. To a much greater extent than is true of Western law, it must include the study of philosophy, religion, classics, history, politics, economics, sociology and psychology. Preoccupation with scrutinizing, analyzing and comparing Chinese statutes and court decisions-a skill which Western lawyers employ with dexterity and felicity-is futile and its results misleading, ${ }^{207}$ since, if devoid of insight into the make-up of Chinese society, such an approach would at best deal with symptoms and not causes. Yet the mastery of the Chinese language itself, let alone that of the Chinese culture, is a life-long process for non-Chinese. Even in this age of automation, individual painstaking, persevering effort cannot be replaced by instant scholarship through committees, conferences, computers or research assistantships. Encouraged though we may be by the efforts of a few American universities to initiate Chinese legal study and a few law professors who have begun the study of the Chinese language, the tasks ahead are arduous and full of pitfalls.

207 See this author's book review of Maung Maung, Law and Custom in Burna and the Burmese Family, 12 AM. J. CoMp. L. 606-09 (1963). 